\title{
Investigating prehistoric diet and lifeways of early farmers in central northern Spain (3000-1500 CAL BC) using stable isotope techniques
}

\author{
Jennifer R. Jones ${ }^{1,2}$. Cristina Vega Maeso ${ }^{1}$. Eduardo Carmona Ballestero ${ }^{3,4} \cdot$ Luis Villanueva Martín ${ }^{5}$. \\ Maria Eugenía Delgado Arceo ${ }^{5}$ Ana B. Marín-Arroyo ${ }^{1,6}$ (D)
}

Received: 28 March 2018 / Accepted: 3 April 2019

(C) Springer-Verlag GmbH Germany, part of Springer Nature 2019

\begin{abstract}
This work focuses on reconstructing past diets and animal management during Prehistory in Central Northern Spain, spanning the NE area of the Old Castilian Plateau to the Cantabrian coast, from c. 3000-1500 BCE. During this time, early farming communities made changes in their models of production and social reproduction that crystallised in the emergence of social complexity. To investigate these changes, we reconstructed the past diet of these early farming populations by using stable isotope analysis $\left(\delta^{13} \mathrm{C}, \delta^{15} \mathrm{~N}, \delta^{34} \mathrm{~S}\right)$ of human and animal remains from the recently excavated sites of Abrigo de la Castañera in Cantabria and Arroyal I, El Hornazo, Fuente Celada and Ferrocarril-La Dehesa in Burgos. The human remains derived from a range of burial contexts including pit graves, megalithic monuments and burial caves. To provide initial insights into animal management during this timeframe, associated faunal remains were also studied as a baseline. In total, 52 samples were analysed, including 17 human burials and 35 animal specimens (cattle, sheep, pig, red deer and dog). Results show that humans in these sites consumed relatively similar diets, comprising of a predominantly $\mathrm{C} 3$ diet including animal protein. Animal management patterns indicate a wider use of the landscape for herbivore grazing. The differing diets of dogs at El Hornazo provide insights into the relationship that they had with humans and tentatively suggests differences in the diet of working animals versus household pets. The $\delta^{34} \mathrm{~S}$ values of two individuals from Arroyal I indicate that they came from different regions, implying a level of inland mobility during the Chalcolithic.
\end{abstract}

Keywords Diet $\cdot$ Stable isotopes $\cdot$ Spain $\cdot$ Prehistory $\cdot$ Neolithic $\cdot$ Chalcolithic $\cdot$ Animal management $\cdot$ Bronze age

Electronic supplementary material The online version of this article (https://doi.org/10.1007/s12520-019-00841-4) contains supplementary material, which is available to authorized users.

Ana B. Marín-Arroyo

marinab@unican.es

1 Instituto Internacional de Investigaciones Prehistóricas de Cantabria, Universidad de Cantabria. (Santander, Gobierno de Cantabria), 39005 Santander, Spain

2 Department of Archaeology, School of Geosciences, University of Aberdeen, Aberdeen AB24 3FX, Scotland

3 Servicio Territorial de Cultura de Valladolid, Junta de Castilla y León, C/ Duque de la Victoria, 8, 47001 Valladolid, Spain

4 Área de Arqueología, Universidad de Burgos, Hospital del Rey, s/n, 09001 Burgos, Spain

5 Antequem, Arqueología y Medio Ambiente, S. L. Laguna de Duero, 47140 Valladolid, Spain

6 Leverhulme Centre for Evolutionary Studies, Department of Archaeology, University of Cambridge, Cambridge CB2 1QH, UK

\section{Introduction}

The arrival of agriculture and livestock to the Iberian Peninsula promoted changes in social and economic structures (Rojo Guerra et al. 2012). The new species and products were linked to a dramatic change in economy that, unlike hunting and gathering, required long-term planning and investment in the production of food, with deferred results (Vicent 1990, 1998 ) and gave rise to a new type of people; farmers. These new agricultural economies needed specific requirements to be able to thrive (e.g. political control over territory, agrarian capital, storage of goods, long-term management of resources). It was mastering these conditions that led to the origins of the first complex societies. The current paradigm, accepted by most scholars (see Bernabeu 2003; Delibes de Castro and Fernández Manzano 2000; Díaz del Rio 2006) is that, such socio-economic political differences began to become visible in the interior and North of the Iberian Peninsula during Chalcolithic (c. 3300-1900 BCE) (Delibes de Castro 
and Fernández Miranda 1993; Delibes de Castro et al. 1995). One of the consequences of the new situation was the emergence of regional differences that are observed within the archaeological record (Bernabeu 2003). For example, the size and type of settlements changed during the Chalcolithic along the Iberian Peninsula (c. 3000-2200 BCE). While small and open settlements dominated, the northern and eastern regions of the peninsula, fortified settlements appeared in the western and southern regions (Garcia Sanjuán and Murillo-Barroso 2013; Rojo Guerra et al. 2005). During the Final Chalcolithic and Early Bronze Age (c. 2200-1900 BCE), there was a diversity and richness of the Bell Beaker settlements and burial assemblages in Iberia (Garrido-Pena 2014). Later, during the Middle and Final Bronze Age (c. 19001000 BCE) in the North and centre of the peninsula, economy and society seem to have stabilised without significant changes, compared to the previous stages (Díaz del Rio 2001, 2006). Nevertheless, little is currently known about the diet and economy of these past populations.

To explore the economy and lifeways of the Prehistoric inhabitants of Central Northern Spain, this research is focused on sites located from the NE of the Castilian Plateau to the Cantabrian coast (Fig. 1) between c. 3000 and 1500 BCE. To date the subsistence strategies of the past populations inhabiting this region are poorly known. From the Northern plateau, Chalcolithic human remains are rare (Carmona Ballestero et al. 2013) and faunal assemblages recorded from such sites are relatively small (Riquelme Cantal 2009; MarínArroyo 2011). The situation is similar in the Cantabrian coast, in the northernmost part of the study region, with few zooarchaeological studies existing from this time period (Altuna 1980; Altuna and Mariezkurrena 2012; Altuna and Mariezkurrena 2011; Castaños 1984; Mariezkurrena 1990; Ontañón Peredo 2003; Peréz Ripoll and López Gila, 2012). Recent excavations at Arroyal I (Carmona Ballestero and Arnaiz Alonso in press), Fuente Celada (Alameda CuencaRomero et al. 2011; Carmona Ballestero 2013) and El Hornazo (Carmona Ballestero 2013; Carmona Ballestero et al. 2013), all located in the province of Burgos, and El Abrigo de la Castañera (Sierra Saínz-Aja 2014) in Cantabria have revealed assemblages of human skeletal remains from mortuary contexts, in addition to associated mammal remains. Dietary stable isotope analysis of these human and animal elements presents a valuable opportunity to understand the economic behaviour of these early farmers, during a period of emerging social complexity.

Fig. 1 Map of the northern Spain showing the location of the sites studied from the Castilian Plateau and the Cantabrian Region

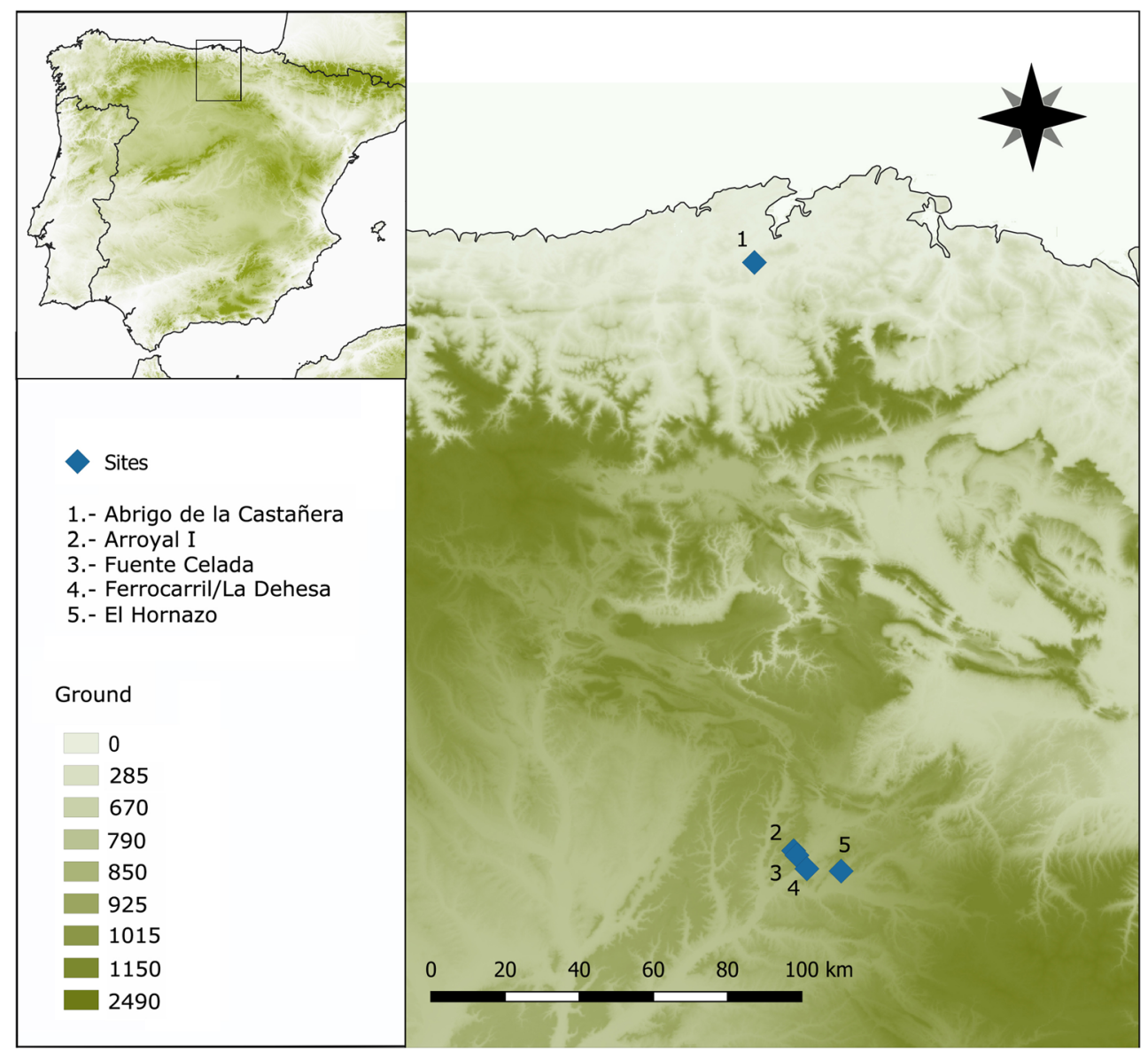


Stable isotope analysis has commonly been used in archaeology since the mid-1980s as a technique for reconstructing palaeodietary behaviour, providing insights into human nutrition and economic strategies (Schoeninger et al. 1983; DeNiro 1985; Schoeninger and DeNiro 1984; Chisholm et al. 1982). Stable isotope analysis of bone collagen is a reflection of diet consumed by an individual over the last 10-15 years of life, informing on long-term average diet. This method is especially valuable in determining $\mathrm{C}_{3}$ and $\mathrm{C}_{4}$ plant consumption (Tieszen 1991), the use of animal protein, and the inclusion of marine foods in diet (Schulting and Richards 2002). Although there have been numerous applications of this technique in Prehistoric Europe (e.g. Richards et al. 1998; Schulting et al. 2010; Oelze et al. 2011; Tafuri et al. 2009), it is only in recent years that this subject has received attention in Spain, with studies attempting to redress this balance in the Mediterranean Coast (Salazar-García et al. 2014) and the Basque Country in the north of Iberia (Fernández-Crespo and Schulting 2017; Fernández-Crespo et al. 2018; Fontanals-Coll et al. 2015; Sarasketa-Gartzia et al. 2018).

Stable isotope analysis of animal bone collagen related to human remains can not only provide a valuable baseline for human diet but also provide valuable insights into animal management practises (e.g. Jones and Mulville 2016, 2018; Stevens et al. 2013; Müldner et al. 2014). In this study, $\delta^{13} \mathrm{C}$ and $\delta^{15} \mathrm{~N}$ analysis of animal bone collagen will also be used to explore the use of the landscape by these early farming populations.

\section{Materials and methods}

The sites included in this comparative study are from Central Northern Spain, spanning the NE area of the Old Castilian Plateau to the Cantabrian coast (Fig. 1). Within this wider geographical region, the sites derive from two environmental zones. Four of the sites (Arroyal I, El Hornazo, Fuente Celada and FerrocarrilLa Dehesa) are located in the NE area of the Spanish North Plateau, an inland region with a cool and dry continental Mediterranean climate. This area is characterised by long and cold winters and short and warm summers and a strong contrast between day and night temperatures. In contrast, El Abrigo de la Castañera is located in the Cantabrian region which has an Atlantic climate and lies close to the coast. The Cantabrian Region today is characterised by year-round rainfall and limited seasonal temperature variation (Peel et al. 2007). The distinctly different environmental conditions of the two regions mean that there is potential for different models of dietary behaviour and animal management. A summary of the samples analysed from each site is presented in Table 1.

\section{The sites}

\section{Arroyal I (Alfoz de Quintanadueñas, Burgos, Castile and León, Spain)}

The site of Arroyal I (Fig. 1) was excavated between 2011 and 2012 by a research team from the University of Burgos. The site is a megalithic tomb comprising of a rectangular chamber $(3 \times 3.5 \mathrm{~m})$, a long corridor $(6 \mathrm{~m})$ and a stone mound. The tomb was used as a collective burial location over a period of 400 years during the Late Neolithic (c. 3300-2900 BCE, Table 2), before it was abandoned (Carmona Ballestero and Arnaiz Alonso in press). During the Chalcolithic, the tomb came back into use when it was extensively remodelled. At that time, Neolithic layers were almost entirely removed; the corridor was filled with rocks and sediment (as a closure event) and a stone wall and a floor of limestone blocks were built inside the chamber. Following this, several consecutive and isolated burials were interred. One of these contained a young individual, dated to c. 2465-2211 BCE (Table 2), that was buried with a set of four vessels (two bell beakers bowls and two carinated ones), surrounded by human long bones and skulls from previous contemporaneous burials. In the next phase of activity, the dolmen was closed re-using materials from the site (in a secondary position) and the external mound height was increased. Finally, an isolated pit grave containing a female human body was created inside the mound, which dateds to c. 2348-2200 BCE (Table 2).

\section{El Hornazo (Villímar, Burgos, Castile and León, Spain)}

El Hornazo is a 'field of pits' located in Villímar, Burgos (Fig. 1). In 2004, a research team excavated an area of almost 1 ha where 179 different structures were discovered, including pits, ditch pits, pit-graves and post holes (Carmona Ballestero 2013). This site represents a Chalcolithic settlement divided into three different activity areas: habitation, storage and resource processing. In the storage area, two pit-graves were documented. The first grave (Pit 103) included a human subadult, buried with a bowl, infilled with sediment and few domestic remains that is dated to c. 2576-2473 BCE. In the second pit (Pit 140), dating to c. 2860-2574 BCE, another subadult was found buried in a crouched position. Deposits within Pit 140 contained domestic remains including pottery and animal bones. A single biconical bead was registered as a gravegood inside Pit 140. AMS dates of the human remains belong to the Pre-Beaker Chalcolithic (Table 2). In conjunction with the radiocarbon dates, the stylistic and typological attributes of archaeological remains determined that the entire aggregate of negative structures were formed during a single phase of occupation. 
Table 1 Summary of the human and animal species sampled for $\delta^{13} \mathrm{C}$ and $\delta^{15} \mathrm{~N}$ analysis from each site

\begin{tabular}{|c|c|c|c|c|c|c|c|c|c|c|c|}
\hline Site & Location & Period & Human & Horse & Cow & Sheep & Ovicaprid & Pig & Red deer & Dog & Total \\
\hline Ferrocarril-La Dehesa & Burgos & Middle Bronze Age & 1 & - & - & - & - & - & - & - & 1 \\
\hline Abrigo de la Castañera & Cantabria & Bronze Age & 3 & - & - & - & 1 & 3 & - & - & 7 \\
\hline El Hornazo & Burgos & Chalcolithic (Pre-Beaker) & 2 & - & 6 & & 4 & & 1 & 4 & 17 \\
\hline Fuente Celada & $=$ & $=$ & 3 & - & 4 & 1 & 3 & & - & - & 11 \\
\hline \multirow[t]{4}{*}{ Arroyal I } & $=$ & Chaluvinulic & & 1 & - & 2 & - & - & - & & 3 \\
\hline & & Chalcolithic (Beaker) & 5 & - & 2 & 1 & - & - & - & 1 & 9 \\
\hline & & Chalcolithic (Non-Beaker) & 2 & - & - & - & - & - & - & - & 2 \\
\hline & & Late Neolithic & 2 & - & - & - & - & - & - & - & 2 \\
\hline Total & & & 18 & 12 & 4 & 1 & 8 & 3 & 1 & 5 & 52 \\
\hline
\end{tabular}

\section{Fuente Celada (Alfoz de Quintadueñas, Burgos, Castile and León, Spain)}

Fuente Celada, located in Quintanadueñas (Burgos), was excavated in 2008 by the same research team of El Hornazo. It is a settlement with many rock-cut pits ('silos') that was occupied initially during the Neolithic and before the main focus of occupation occurred in the Early Chalcolithic (Alameda Cuenca-Romero et al. 2011; Carmona Ballestero 2013). In addition to a more domestic area (containing 'silos', post holes, mud fragments used in the huts, stone mortars and other domestic remains), human remains were discovered inside several pits, dating to the Chalcolithic between c. 2900 and 1900 BCE. Pit 19 contained a young woman, buried in an unusual inverted position (almost vertically placed, with the head at the bottom and the feet at the top). This pit also contained the largest accumulation of potsherds found at the site (1018 fragments, $19.5 \%$ of the total) dated to c. 2860 2574 BCE. In Pit 5, the disarticulated human remains of three individuals (a subadult and two male adults) were recorded, also belonging to the Chalcolithic (Table 2).

\section{Ferrocarril-La Dehesa (Alfoz de Quintadueñas, Burgos, Castile and León, Spain)}

Ferrocarril-La Dehesa is also located in Quintanadueñas (Fig. 1). The site was partially excavated in 1981 by opening a small sondage, before an open excavation area was conducted by L. Villanueva Martín and M. E. Delgado Arceo in 2016. In total, 147 contexts or activity areas were registered within this settlement: most of them simple rock-cut pits ('silos') but with a few dwellings, kilns and a pit-grave. In all cases, the features were filled with deposits containing domestic remains. The site is dated by relative methods with the Cogotas I type pottery, either in its formative phase (Protocogotas) or advanced phase one (Cogotas I Pleno) to the Middle Bronze Age (c. 1750-1450 BCE). The tomb (Pit 700) included an adult individual, deposited in a foetal position without any grave goods.

\section{El Abrigo de la Castañera (Obregón, Cantabria, Spain)}

El Abrigo de La Castañera is situated in the south of Santander Bay, in Cantabria (Fig. 1). This is the only site in this study that is located near the Atlantic Sea, which has a distinctive climatic and environmental context in comparison to the sites located in the province of Burgos. The site is an $85-\mathrm{m}^{2}$ deep rock shelter, that is a part of a seven-cave karst complex, oriented towards the NE. The site was surveyed in the late 1960s (Gomarín Guirado 1972) and partially excavated during the 1970s (Rincón Vila 1982, 1985). Later, it was subsequently studied by local archaeologists (Ruiz Cobo and Serna González, 1999; Ruiz Cobo 1991, 1996). Since 2011, a multidisciplinary research team led by $\mathrm{C}$. Vega-Maeso has been excavating the shelter and surveying its surroundings.

The rock shelter has evidence of domestic use, including living areas, and an animal corral, during the Neolithic and Chalcolithic. A well-preserved Bronze Age stratigraphy linked to funerary events (c. 2100-1500 BCE, Table 2) was also recorded within the shelter (Vega-Maeso 2017). During recent excavations, human remains from at least six individuals were recovered associated with faunal remains (including domestic and wild species), lithic and bone industry, shells and pottery (Sierra Sainz-Aja 2014).

\section{Sample preparation}

Samples were prepared using facilities in the Institute of Biomedicine and Biotechnology at the University of Cantabria in Spain. Collagen extraction was undertaken following procedures outlined in Richards and Hedges (1999). Bone fragments between 0.6 and $0.8 \mathrm{~g}$ were cleaned by abrasion to remove any possible surface contamination before demineralisation in $0.5 \mathrm{M} \mathrm{HCL}$ at $6-8{ }^{\circ} \mathrm{C}$ for between 3 and 10 days. Samples were then washed using de-ionised water. Samples were gelatinised in a weak acidic solution $(\mathrm{pH} 3$ $\mathrm{HCL})$ at $70{ }^{\circ} \mathrm{C}$ for $48 \mathrm{~h}$, then filtered with 5-8 $\mu \mathrm{m}$ Ezee $\AA$ filters, prior to freeze-drying. Samples were analysed for $\delta^{13} \mathrm{C}, \delta^{15} \mathrm{~N}$ and two samples were additionally analysed for 
Table 2 Radiometric dates available from Arroyal I, El Hornazo Fuente Celada in Burgos and Abrigo de la Castañera in Cantabria

\begin{tabular}{|c|c|c|c|c|c|c|c|}
\hline Site & ID & $\begin{array}{l}\text { Date } \\
\text { B.P. }\end{array}$ & Date calibrated $2 \sigma$ & Species/material & $\begin{array}{l}\text { Activity } \\
\text { area/context }\end{array}$ & $\begin{array}{l}\text { Period/ } \\
\text { archaeological } \\
\text { group }\end{array}$ & Reference \\
\hline Arroyal I & UGAMS-15903 & 3870,30 & $\begin{array}{l}2465 \mathrm{BC}(89.7 \%) \\
2278 \mathrm{BC} \\
2250 \mathrm{BC}(4.3 \%) \\
2229 \mathrm{BC} \\
2220 \mathrm{BC}(1.4 \%) \\
2211 \mathrm{BC}\end{array}$ & $\begin{array}{l}\text { Human bone } \\
\text { collagen }\end{array}$ & $\begin{array}{l}\text { SU } 25 \\
\text { Inhumation } \\
2\end{array}$ & $\begin{array}{l}\text { Chalcolithic } \\
\text { (Beaker) }\end{array}$ & $\begin{array}{l}\text { Carmona and Arnaiz } \\
\text { (in press) }\end{array}$ \\
\hline Arroyal I & UGAMS-15904 & 3850,30 & $\begin{array}{l}2458 \mathrm{BC}(75.7 \%) \\
2269 \mathrm{BC} \\
2260 \mathrm{BC}(19.7 \%) \\
2206 \mathrm{BC}\end{array}$ & $\begin{array}{c}\text { Human bone } \\
\text { collagen }\end{array}$ & SU 25, skull 1 & $\begin{array}{l}\text { Chalcolithic } \\
\text { (Beaker) }\end{array}$ & $\begin{array}{l}\text { Carmona and Arnaiz } \\
\text { (in press) }\end{array}$ \\
\hline Arroyal I & UGAMS-15905 & 3860,30 & $\begin{array}{l}2461 \mathrm{BC}(84.3 \%) \\
2276 \mathrm{BC} \\
2254 \mathrm{BC}(11.1 \%) \\
2210 \mathrm{BC}\end{array}$ & $\begin{array}{l}\text { Human bone } \\
\text { collagen }\end{array}$ & SU 25.skull 2 & $\begin{array}{l}\text { Chalcolithic } \\
\text { (Beaker) }\end{array}$ & $\begin{array}{l}\text { Carmona and Arnaiz } \\
\text { (in press) }\end{array}$ \\
\hline Arroyal I & UGAMS-15906 & 4370,30 & $\begin{array}{c}3089 \mathrm{BC}(9.7 \%) \\
3054 \mathrm{BC} \\
3031 \mathrm{BC}(85.7 \%) \\
2907 \mathrm{BC}\end{array}$ & $\begin{array}{c}\text { Human bone } \\
\text { collagen }\end{array}$ & SU 10 & Late Neolithic & $\begin{array}{l}\text { Carmona and Arnaiz } \\
\text { (in press) }\end{array}$ \\
\hline Arroyal I & UGAMS-15907 & 4410,30 & $\begin{array}{l}3309 \mathrm{BC}(0.7 \%) \\
3299 \mathrm{BC} \\
3283 \mathrm{BC}(0.5 \%) \\
3276 \mathrm{BC} \\
3265 \mathrm{BC}(4.1 \%) \\
3240 \mathrm{BC} \\
3106 \mathrm{BC}(90.2 \%) \\
2917 \mathrm{BC}\end{array}$ & $\begin{array}{l}\text { Human bone } \\
\text { collagen }\end{array}$ & SU 34 & Late Neolithic & $\begin{array}{l}\text { Carmona and Arnaiz } \\
\text { (in press) }\end{array}$ \\
\hline Arroyal I & UGAMS-15908 & 4430,30 & $\begin{array}{c}3326 \mathrm{BC}(20.7 \%) \\
3231 \mathrm{BC} \\
3224 \mathrm{BC}(0.4 \%) \\
3220 \mathrm{BC} \\
3174 \mathrm{BC}(1.8 \%) \\
3160 \mathrm{BC} \\
3120 \mathrm{BC}(72.4 \%) \\
2926 \mathrm{BC}\end{array}$ & $\begin{array}{l}\text { Human bone } \\
\text { collagen }\end{array}$ & SU 39 & Late Neolithic & $\begin{array}{l}\text { Carmona and Arnaiz } \\
\text { (in press) }\end{array}$ \\
\hline Arroyal I & MAMS-14857 & 3837,25 & $\begin{array}{l}2348 \mathrm{BC}(95.4 \%) \\
2200 \mathrm{BC}\end{array}$ & $\begin{array}{l}\text { Human bone } \\
\text { collagen }\end{array}$ & SU 19 & $\begin{array}{l}\text { Chalcolithic } \\
\text { (Non-Beaker) }\end{array}$ & $\begin{array}{l}\text { Carmona and Arnaiz } \\
\text { (in press) }\end{array}$ \\
\hline Arroyal I & $15 \mathrm{~B} / 0254$ & 3860,40 & $\begin{array}{l}2431 \mathrm{BC} \\
(93.3 \%) 2262 \mathrm{BC} \\
2254 \mathrm{BC}(2.1 \%) \\
2210 \mathrm{BC}\end{array}$ & $\begin{array}{l}\text { Human bone } \\
\text { collagen }\end{array}$ & SU 21 & $\begin{array}{l}\text { Chalcolithic } \\
\text { (Non-Beaker) }\end{array}$ & $\begin{array}{l}\text { Carmona and Arnaiz } \\
\text { (in press) }\end{array}$ \\
\hline El Hornazo & UGAMS-7566 & 4290,25 & $2927(95.4 \%) 2878$ & $\begin{array}{l}\text { Animal Bone } \\
\text { collagen }\end{array}$ & Pit 94, SU 958 & $\begin{array}{l}\text { Chalcolithic } \\
\text { (Pre-Beaker) }\end{array}$ & Carmona 2013 \\
\hline El Hornazo & UGAMS-8820 & 4200,25 & $\begin{array}{l}2893(27.5 \%) 2850 \\
2814(52.9 \%) 2741 \\
2729(14.4 \%) 2694 \\
2685(0.7 \%) 2680\end{array}$ & Seed & Pit 30; SU 303 & $\begin{array}{l}\text { Chalcolithic } \\
\text { (Pre-Beaker) }\end{array}$ & Carmona 2013 \\
\hline El Hornazo & UGAMS-6838 & 4010,25 & $2576(95.4 \%) 2473$ & $\begin{array}{l}\text { Human bone } \\
\text { collagen }\end{array}$ & $\begin{array}{l}\text { Pit 103; } \\
\quad \text { SU1031 }\end{array}$ & $\begin{array}{l}\text { Chalcolithic } \\
\text { (Pre-Beaker) }\end{array}$ & Carmona 2013 \\
\hline El Hornazo & UGAMS-6995 & 4100,25 & $\begin{array}{l}2860(22.1 \%) 2809 \\
2752(8.0 \%) 2721 \\
2702(65.3 \%) 2574\end{array}$ & $\begin{array}{l}\text { Human bone } \\
\text { collagen }\end{array}$ & $\begin{array}{l}\text { Pit 140; } \\
\quad \text { SU1401 }\end{array}$ & $\begin{array}{l}\text { Chalcolithic } \\
\text { (Pre-Beaker) }\end{array}$ & Carmona 2013 \\
\hline Fuente Celada & UGAMS-7565 & 6120,30 & $\begin{array}{l}5208(23.4 \%) 5144 \\
5139(9.4 \%) 5091 \\
5083(62.6 \%) 4961\end{array}$ & $\begin{array}{l}\text { Human bone } \\
\text { collagen }\end{array}$ & Pit 62 , SU 622 & Early Neolithic & Carmona 2013 \\
\hline Fuente Celada & UGAMS-7563 & 4200,25 & $\begin{array}{l}2893(27.5 \%) 2850 \\
2814(52.9 \%) 2741 \\
2729(14.4 \%) 2694 \\
2687(0.7 \%) 2680\end{array}$ & $\begin{array}{c}\text { Animal bone } \\
\text { collagen }\end{array}$ & Pit 42; SU 424 & $\begin{array}{l}\text { Chalcolithic } \\
\text { (Pre-Beaker) }\end{array}$ & Carmona 2013 \\
\hline Fuente Celada & UGAMS-7561 & 4170,25 & $\begin{array}{l}2880(19.8 \%) 2835 \\
2817(75.1 \%) 2667\end{array}$ & $\begin{array}{l}\text { Animal bone } \\
\text { collagen }\end{array}$ & $\begin{array}{l}\text { Pit H15; SU } \\
\quad 152\end{array}$ & $\begin{array}{l}\text { Chalcolithic } \\
\text { (Pre-Beaker) }\end{array}$ & Carmona 2013 \\
\hline
\end{tabular}


Table 2 (continued)

\begin{tabular}{|c|c|c|c|c|c|c|c|}
\hline Site & ID & $\begin{array}{l}\text { Date } \\
\text { B.P. }\end{array}$ & Date calibrated $2 \sigma$ & Species/material & $\begin{array}{l}\text { Activity } \\
\text { area/context }\end{array}$ & $\begin{array}{l}\text { Period/ } \\
\text { archaeological } \\
\text { group }\end{array}$ & Reference \\
\hline Fuente Celada & UGAMS-7559 & 4100,25 & $\begin{array}{l}2643(0.5 \%) 2640 \\
2860(22.1 \%) 2809 \\
2752(8.0 \%) 2721 \\
2702(65.3 \%) 2574\end{array}$ & $\begin{array}{l}\text { Human bone } \\
\text { collagen }\end{array}$ & $\begin{array}{l}\text { Pit 5; SU 53, } \\
\quad \text { indiv. } 2\end{array}$ & $\begin{array}{l}\text { Chalcolithic } \\
\text { (Pre-Beaker) }\end{array}$ & Carmona 2013 \\
\hline Fuente Celada & UGAMS-7562 & 4100,25 & $\begin{array}{l}2860(22.1 \%) 2809 \\
2752(8.0 \%) 2721 \\
2702(65.3 \%) 2574\end{array}$ & $\begin{array}{l}\text { Human bone } \\
\text { collagen }\end{array}$ & Pit 19; SU 193 & $\begin{array}{l}\text { Chalcolithic } \\
\text { (Pre-Beaker) }\end{array}$ & Carmona 2013 \\
\hline Fuente Celada & UGAMS-7560 & 4030,25 & $2620(95.4 \%) 2474$ & $\begin{array}{l}\text { Human bone } \\
\text { collagen }\end{array}$ & $\begin{array}{l}\text { Pit 5; SU 53, } \\
\text { indiv. } 3\end{array}$ & $\begin{array}{l}\text { Chalcolithic } \\
\text { (Pre-Beaker) }\end{array}$ & Carmona 2013 \\
\hline Fuente Celada & UGAMS-7564 & 3790,25 & $2292(95.4 \%) 2140$ & $\begin{array}{l}\text { Animal bone } \\
\text { collagen }\end{array}$ & Pit 60; SU 601 & $\begin{array}{l}\text { Chalcolithic } \\
\text { (Non-Beaker) }\end{array}$ & Carmona 2013 \\
\hline $\begin{array}{l}\text { Abrigo de la } \\
\text { Castañera }\end{array}$ & UGAMS-10907 & 3290,25 & $1623(95.4 \%) 1507$ & $\begin{array}{l}\text { Animal bone } \\
\text { collagen }\end{array}$ & SU 1 & Early Bronze Age & Vega Maeso 2017 \\
\hline $\begin{array}{l}\text { Abrigo de la } \\
\text { Castañera }\end{array}$ & UGAMS-16015 & 3530,25 & $1935(95.4 \%) 1771$ & $\begin{array}{l}\text { Human bone } \\
\text { collagen }\end{array}$ & SU 105 & Early Bronze Age & Vega Maeso 2017 \\
\hline $\begin{array}{l}\text { Abrigo de la } \\
\text { Castañera }\end{array}$ & UGAMS-10908 & 3590,25 & $\begin{array}{l}2022(14.4 \%) 1990 \\
1985(81.0 \%) 1888\end{array}$ & $\begin{array}{l}\text { Human bone } \\
\text { collagen }\end{array}$ & SU 2 & Early Bronze Age & Vega Maeso 2017 \\
\hline $\begin{array}{l}\text { Abrigo de la } \\
\text { Castañera }\end{array}$ & ICA14B/1116 & 3750,40 & $2286(95.4 \%) 2035$ & $\begin{array}{l}\text { Human bone } \\
\text { collagen }\end{array}$ & SU 3 & Early Bronze Age & Vega Maeso 2017 \\
\hline
\end{tabular}

$\delta^{34} \mathrm{~S}$ (samples SUC28 and SUC19) using mass spectrometry at Iso-Analytical (Crewe, UK).

The $\delta^{13} \mathrm{C}$ values and $\delta^{15} \mathrm{~N}$ values are reported relative to the international standards V-PDB and AIR standards. Inhouse standards were used to calculate analytical error which was $\pm 0.1 \%$ o $(1 \sigma)$ or better. All specimens discussed further had $\% \mathrm{C}$ values above $35 \%, \% \mathrm{~N}$ values above $15 \%$ and $\mathrm{C}: \mathrm{N}$ values between 2.9 and 3.4 indicative of in vivo collagen (De Niro 1985; van Klinken 1999). The $\delta^{34} \mathrm{~S}$ values are reported relative to the international standard VCDT. Quality indicators of C:S values between $600 \pm 300$ and N:S values between 200 \pm 100 (Nehlich and Richards 2009). All sample information, raw data and quality indicators for each sample are included in the Supplementary Material.

\section{Results and interpretation}

The results obtained are presented alongside initial interpretation about human diet and animal management at each archaeological site. The subsequent discussion is focused on the wider implications of these results in terms of the Prehistoric economies and lifeways in Central Northern Spain.

\section{Arroyal I (Alfoz de Quintanadueñas, Burgos, Castile and León, Spain)}

The human stable isotope values from Arroyal I $(n=9)$ form a main cluster of individuals dated to the Late Neolithic, Chalcolithic and Beaker period, with $\delta^{13} \mathrm{C}$ values ranging between $-19.3 \%$ and $-19.7 \%$, and $\delta^{15} \mathrm{~N}$ values ranging between 9.2 and 10.9\%o (Fig. 2; Fig. 3). One individual (SUC28) plotted away from this main cluster with a lower $\delta^{13} \mathrm{C}$ value of $-20.8 \%$, while the $\delta^{15} \mathrm{~N}$ value of $10.3 \%$ is similar to the $\delta^{15} \mathrm{~N}$ values observed in the main cluster. The humans have $\delta^{15} \mathrm{~N}$ values 3-4\%o higher than the herbivores sampled from the site, which is a typical relationship between consumers and prey during the Holocene (Hedges and Reynard 2007) and suggests that the humans were eating a $C_{3}$ diet that included animal protein (meat and potentially milk).

Individual SUC28 appears to have consumed a different diet to the other humans sampled based on the $\delta^{13} \mathrm{C}$ values observed. To explore the relationship of this individual and the main cluster, $\delta^{34} \mathrm{~S}$ analysis was undertaken. Collagen from SUC28 and SUC19 was analysed to explore whether these individuals were derived from the same place. SUC28 yielded a $\delta^{34} \mathrm{~S}$ value of $14.8 \%$ and SUC19 had a $\delta^{34} \mathrm{~S}$ value of $10.2 \%$ (Table 3) indicating that these individuals derived from regions that were isotopically different in sulphur, likely representing geographically distinct locations.

\section{El Hornazo (Villímar, Burgos, Castile and León, Spain)}

The Chalcolithic humans from El Hornazo $(n=2)$, have $\delta^{13} \mathrm{C}$ values between -19.2 and $-19.7 \%$ and $\delta^{15} \mathrm{~N}$ values of $8.6 \%$ o and $9.5 \%$ (Fig. 3; Table 3), indicative of terrestrial diet of animal protein in addition to plant products. One of the four dogs sampled has values indistinguishable from the humans analysed $\left(\delta^{13} \mathrm{C}-19.1 \%\right.$ o, $\delta^{15} \mathrm{~N} 8.2 \%$ ) . The other dog specimens plotted have $\delta^{15} \mathrm{~N}$ values ranging between $6.3 \%$ and $6.4 \%$ and $\delta^{13} \mathrm{C}$ values between $-20.2 \%$ and $-20.7 \%$, demonstrating differing dietary behaviour of dogs at the site. The 
Fig. 2 Human and animal bone collagen $\delta^{15} \mathrm{~N}$ and $\delta^{13} \mathrm{C}$ values analysed from Arroyal I

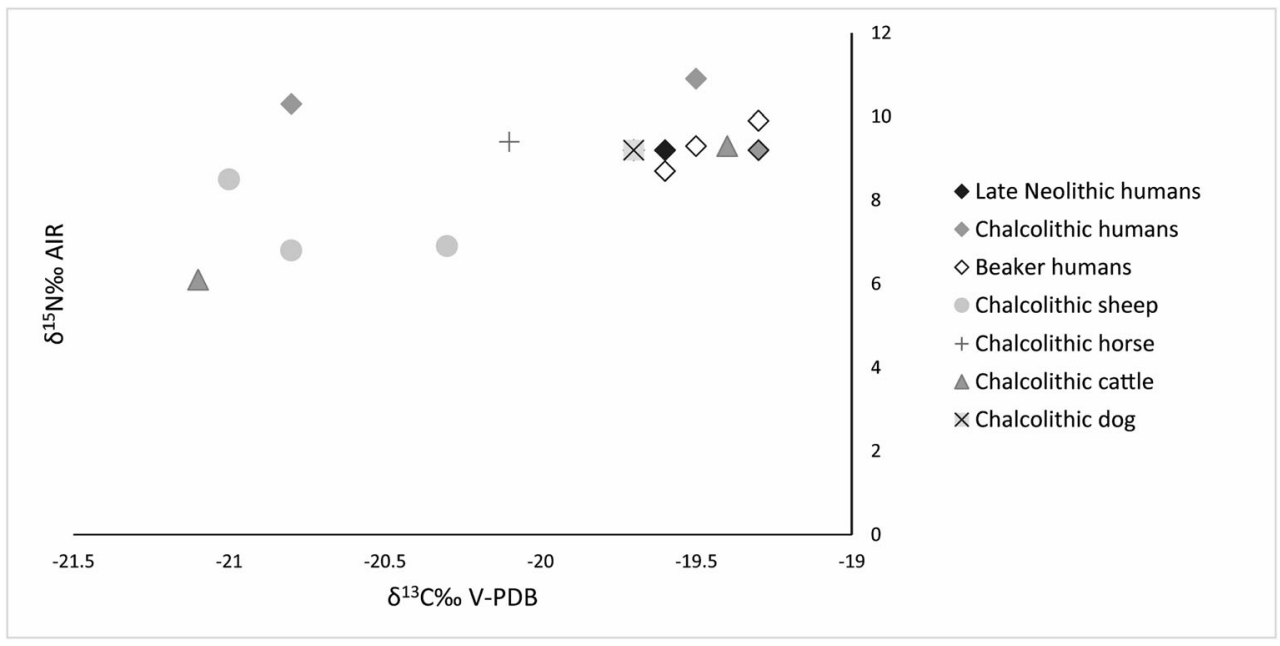

cattle have $\delta^{15} \mathrm{~N}$ values ranging between $5.3 \%$ and $8.3 \%$, with $\delta^{13} \mathrm{C}$ values lying between -19.3 and $-20.8 \%$ (Fig. $3)$. Two of the ovicaprids and one cow are plotted with the human specimens exhibiting higher $\delta^{13} \mathrm{C}$ and $\delta^{15} \mathrm{~N}$ values. Cow 'a' (Fig. 3) had a lower $\delta^{13} \mathrm{C}$ value of $-19.3 \%$.

\section{Fuente Celada (Alfoz de Quintadueñas, Burgos, Castile and León, Spain)}

The Fuente Celada humans $(n=3)$, dating to the Chalcolithic, had $\delta{ }^{13} \mathrm{C}$ values ranging between -19.3 and $-19.5 \%$ and $\delta^{15} \mathrm{~N} \%$ o values ranging between 8.3 and $9.2 \%$ (Fig. 4; Table 3). The tight range in values observed suggests that these individuals consumed a very similar diet, including terrestrial animal protein.

The faunal data show a wide dispersal of stable isotope values. Whilst the sheep and ovicaprids had a relatively small range in $\delta^{13} \mathrm{C}$ values of between $-20.1 \%$ and $-20.7 \%$, the $\delta^{15} \mathrm{~N}$ values were much greater, between $4.3 \%$ and $6.8 \%$. The larger range in $\delta^{15} \mathrm{~N}$ values could indicate a greater diversity in the diet of these animals, potentially representing different pasturing locations or differences in winter foddering within the population analysed.

The cattle from the site have a wider range in $\delta^{13} \mathrm{C}$ values between $-20.4 \%$ and $-21.3 \%$ and a smaller $\delta^{15} \mathrm{~N}$ range than the ovicaprids, between $4.8 \%$ and $5.4 \%$. The wider range of $\delta^{13} \mathrm{C}$ values could also be indicative of differing management practises of individuals, such as the use of a variety of pastures or foddering animals on differing plants.

\section{Ferrocarril-La Dehesa (Alfoz de Quintadueñas, Burgos, Castile and León, Spain)}

Only one human specimen was available to study from this site and attributed to the Middle Bronze Age. This individual is plotted next to the Chalcolithic specimens of Fuente Celada, located in the same village (Fig. 4). The individual from Ferrocarril-La Dehesa has a $\delta^{13} \mathrm{C}$ value of $-19.6 \%$ and $\delta^{15} \mathrm{~N}$ value of $9.1 \%$ implying a diet rich in animal protein as seen in neighbouring Fuente Celada.
Fig. 3 Human and animal bone collagen $\delta^{15} \mathrm{~N}$ and $\delta^{13} \mathrm{C}$ values analysed from El Hornazo. The specimen labelled as ' $a$ ' is discussed in more detail in the text

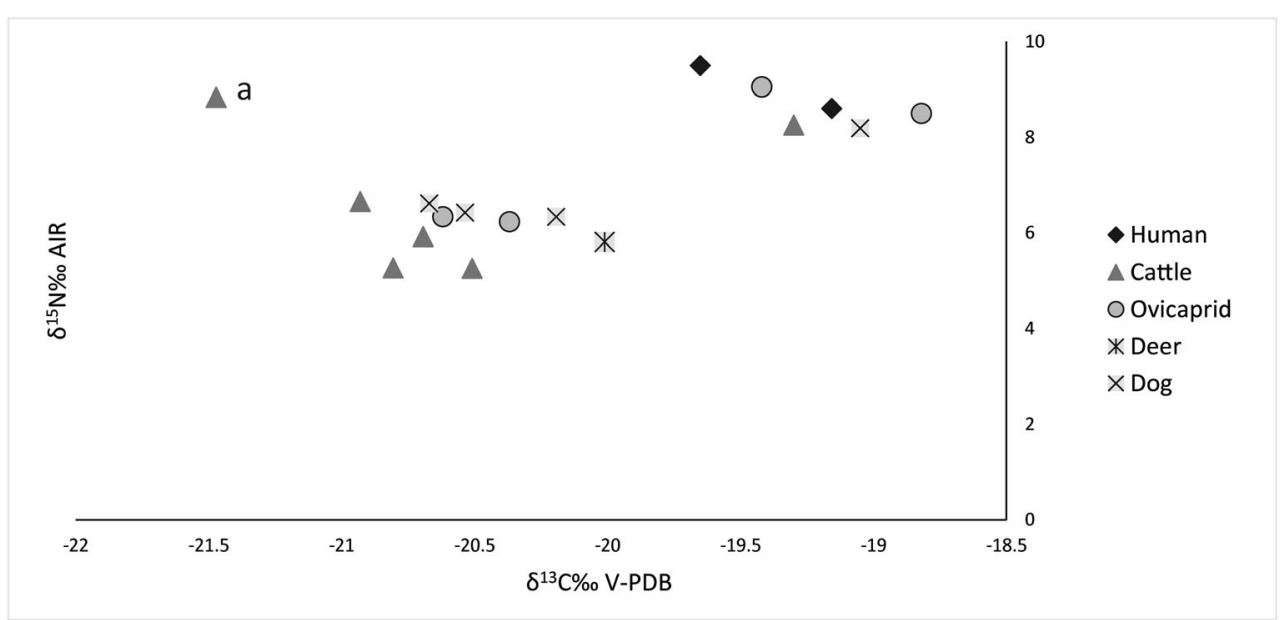


Table 3 Human and animal $\delta^{15} \mathrm{~N}, \delta^{13} \mathrm{C}$, and $\delta^{34} \mathrm{~S}$ values from each of the sites analysed in this study

\begin{tabular}{|c|c|c|c|c|c|c|}
\hline Site & Lab number & Period & Species & $\delta^{15} \mathrm{~N} \%$ & $\delta^{13} \mathrm{C} \%$ & $\delta^{34} \mathrm{~S} \% 0$ \\
\hline Arroyal I & S-UC 12 & Late Neolithic & Human & 9.2 & -19.6 & - \\
\hline Arroyal I & S-UC 28 & Chalcolithic & Human & 10.3 & -20.8 & 14.8 \\
\hline Arroyal I & S-UC 13 & Chalcolithic & Human & 9.2 & -19.3 & - \\
\hline Arroyal I & S-UC 14 & Chalcolithic & Human & 10.9 & -19.5 & - \\
\hline Arroyal I & S-UC 15 & Late Neolithic & Human & 9.2 & -19.7 & - \\
\hline Arroyal I & S-UC 16 & Beaker & Human & 9.2 & -19.3 & - \\
\hline Arroyal I & S-UC 17 & Beaker & Human & 8.7 & -19.6 & - \\
\hline Arroyal I & S-UC 18 & Beaker & Human & 9.3 & -19.5 & - \\
\hline Arroyal I & S-UC 19 & Beaker & Human & 9.9 & -19.3 & 10.2 \\
\hline Arroyal I & S-UC 20 & Chalcolithic & Sheep & 6.8 & -20.8 & - \\
\hline Arroyal I & S-UC 21 & Chalcolithic & Horse & 9.4 & -20.1 & - \\
\hline Arroyal I & S-UC 22 & Chalcolithic & sheep & 6.9 & -20.3 & - \\
\hline Arroyal I & S-UC 23 & Chalcolithic & Sheep & 8.5 & -21.0 & - \\
\hline Arroyal I & S-UC 24 & Chalcolithic & Dog & 9.2 & -19.7 & - \\
\hline Arroyal I & S-UC 25 & Chalcolithic & Cow & 6.1 & -21.1 & - \\
\hline Arroyal I & S-UC 26 & Chalcolithic & Cow & 9.3 & -19.4 & - \\
\hline El Hornazo & S-UC262 & Chalcolithic & Human & 8.6 & -19.2 & - \\
\hline El Hornazo & S-UC263 & Chalcolithic & Human & 9.5 & -19.7 & - \\
\hline El Hornazo & S-UC264 & Chalcolithic & Cow & 8.3 & -19.3 & - \\
\hline El Hornazo & S-UC265 & Chalcolithic & Dog & 8.2 & -19.1 & - \\
\hline El Hornazo & S-UC266 & Chalcolithic & Ovicaprid & 9.0 & -19.4 & - \\
\hline El Hornazo & S-UC267 & Chalcolithic & Ovicaprid & 8.5 & -18.8 & - \\
\hline El Hornazo & S-UC268 & Chalcolithic & Cow & 6.7 & -20.9 & - \\
\hline El Hornazo & S-UC269 & Chalcolithic & Ovicaprid & 6.3 & -20.6 & - \\
\hline El Hornazo & S-UC270 & Chalcolithic & Ovicaprid & 6.2 & -20.4 & - \\
\hline El Hornazo & S-UC271 & Chalcolithic & Cow & 5.3 & -20.5 & - \\
\hline El Hornazo & S-UC272 & Chalcolithic & Cow & 5.9 & -20.7 & - \\
\hline El Hornazo & S-UC273 & Chalcolithic & Deer & 5.8 & -20.0 & - \\
\hline El Hornazo & S-UC274 & Chalcolithic & Dog & 6.6 & -20.7 & - \\
\hline El Hornazo & S-UC275 & Chalcolithic & Cow & 8.8 & -21.5 & - \\
\hline El Hornazo & S-UC276 & Chalcolithic & Dog & 6.3 & -20.2 & - \\
\hline El Hornazo & S-UC277 & Chalcolithic & Dog & 6.4 & -20.5 & - \\
\hline El Hornazo & S-UC278 & Chalcolithic & Cow & 5.3 & -20.8 & - \\
\hline Fuente Celada & S-UC279 & Chalcolithic & Human & 8.9 & -19.3 & - \\
\hline Fuente Celada & S-UC280 & Chalcolithic & Human & 9.2 & -19.2 & - \\
\hline Fuente Celada & S-UC281 & Chalcolithic & Human & 8.3 & -19.5 & - \\
\hline Fuente Celada & S-UC282 & Chalcolithic & Cow & 4.8 & -20.6 & - \\
\hline Fuente Celada & S-UC284 & Chalcolithic & Cow & 5.3 & -20.8 & - \\
\hline Fuente Celada & S-UC285 & Chalcolithic & Cow & 4.9 & -20.4 & - \\
\hline Fuente Celada & S-UC286 & Chalcolithic & Cow & 5.4 & -21.3 & - \\
\hline Fuente Celada & S-UC287 & Chalcolithic & Sheep & 5.8 & -20.3 & - \\
\hline Fuente Celada & S-UC288 & Chalcolithic & Ovicaprid & 6.8 & -20.7 & - \\
\hline Fuente Celada & S-UC289 & Chalcolithic & Ovicaprid & 4.3 & -20.5 & - \\
\hline Fuente Celada & S-UC290 & Chalcolithic & Ovicaprid & 6.4 & -20.1 & - \\
\hline Ferrocarril-La Dehesa & S-UC261 & Middle Bronze Age & Human & 9.1 & -19.6 & - \\
\hline Abrigo de la Castañera & S-UC01 & Early Bronze Age & Pig & 5.2 & -22.0 & - \\
\hline Abrigo de la Castañera & S-UC06 & Early Bronze Age & Pig & 4.9 & -21.2 & - \\
\hline Abrigo de la Castañera & S-UC07 & Early Bronze Age & Ovicaprid & 3.7 & -21.6 & - \\
\hline Abrigo de la Castañera & S-UC08 & Early Bronze Age & Pig & 3.0 & -23.0 & - \\
\hline
\end{tabular}


Table 3 (continued)

\begin{tabular}{|c|c|c|c|c|c|c|}
\hline Site & Lab number & Period & Species & $\delta^{15} \mathrm{~N} \%$ & $\delta^{13} \mathrm{C} \%$ & $\delta^{34} \mathrm{~S} \%$ \\
\hline Abrigo de la Castañera & S-UC09 & Early Bronze Age & Human & 9.3 & -20.8 & - \\
\hline Abrigo de la Castañera & S-UC10 & Early Bronze Age & Human & 9.5 & -21.3 & - \\
\hline Abrigo de la Castañera & S-UC11 & Early Bronze Age & Human & 10.1 & -20.6 & - \\
\hline
\end{tabular}

El Abrigo de la Castañera (Obregón, Cantabria, Spain)

The humans analysed from El Abrigo de la Castañera $(n=3)$ belong to the Early Bronze Age and have $\delta^{13} \mathrm{C}$ values ranging between $-21.3 \%$ and $-20.8 \%$ and $\delta^{15} \mathrm{~N}$ values ranging between 9.2 and $10.1 \%$ (Table 3; Fig. 5). This is indicative of a diet comprising of animal protein, mirroring the pattern seen at El Hornazo, Fuente Celada, Arroyal I and the individual from Ferrocarril-La Dehesa.

All humans and animals have lower $\delta^{13} \mathrm{C}$ values than seen at the other sites (Figs. 5 and 6). This difference could be due to the location of La Castañera, which is in Cantabria, whereas the other sites are analysed from Burgos. Cantabria is a distinctive region, with the Atlantic Ocean running along the northern edge and the mountain range of the Cantabrian Cordillera to the South, making it climatically different to the Northern Meseta. Few contemporary studies from Northern Spain exist, but red deer sampled from Neolithic, Chalcolithic and Bronze Age levels at El Mirón Cave, also located in Cantabria, have $\delta^{13} \mathrm{C}$ values ranging between -22.2 and $-20.9 \%$ (Stevens et al. 2014). The environmental differences between these two regions likely explain the difference in $\delta^{13} \mathrm{C}$ values seen between El Abrigo de la Castañera and the other sites studied.

Of the faunal remains analysed, two of the three pigs have stable isotope values typical of consuming in an open landscape with $\delta^{13} \mathrm{C}$ values of $-22.0 \%$ and $-21.2 \%$ (Fig. 5; Table 3). The other pig specimen has a much lower $\delta^{13} \mathrm{C}$ value of $-23.0 \%$ (Fig. 5; Table 3), which is typical of an animal feeding in a forested environment, under the influence of the canopy effect (Van der Merwe and Medina 1991).

\section{Discussion}

\section{Diet in early prehistoric northern Spain}

The $\delta^{13} \mathrm{C}$ values of the humans and animals analysed were consistent with individuals consuming a diet dominated by terrestrial $\mathrm{C}_{3}$ resources expected for this time period (Fig. 6). At Arroyal I, Fuente Celada and El Hornazo, there was a trend towards human $\delta^{13} \mathrm{C}$ values being higher than $-20 \%$ o (Fig. 6). This is not unusual for Southern Europe, where a notable difference to Northern Europe is observed, with the latter typically falling within values of -23 to $-20 \%$ (Ambrose 1993; Pollard 2007) and represents different environmental and climatic conditions between European regions.

The sites represent different burial types and chronological periods, with Arroyal I being a megalithic monument, Fuente Celada containing several pit human burials, an individual burial from Ferrocarril-La Dehesa, also found in a pit grave, and burials within the rockshelter of La Castañera. Despite differences in chronology and burial type, the stable isotope evidence of diet for all individuals were remarkably similar (aside from the $\delta^{13} \mathrm{C}$ values at El Abrigo de la Castañera

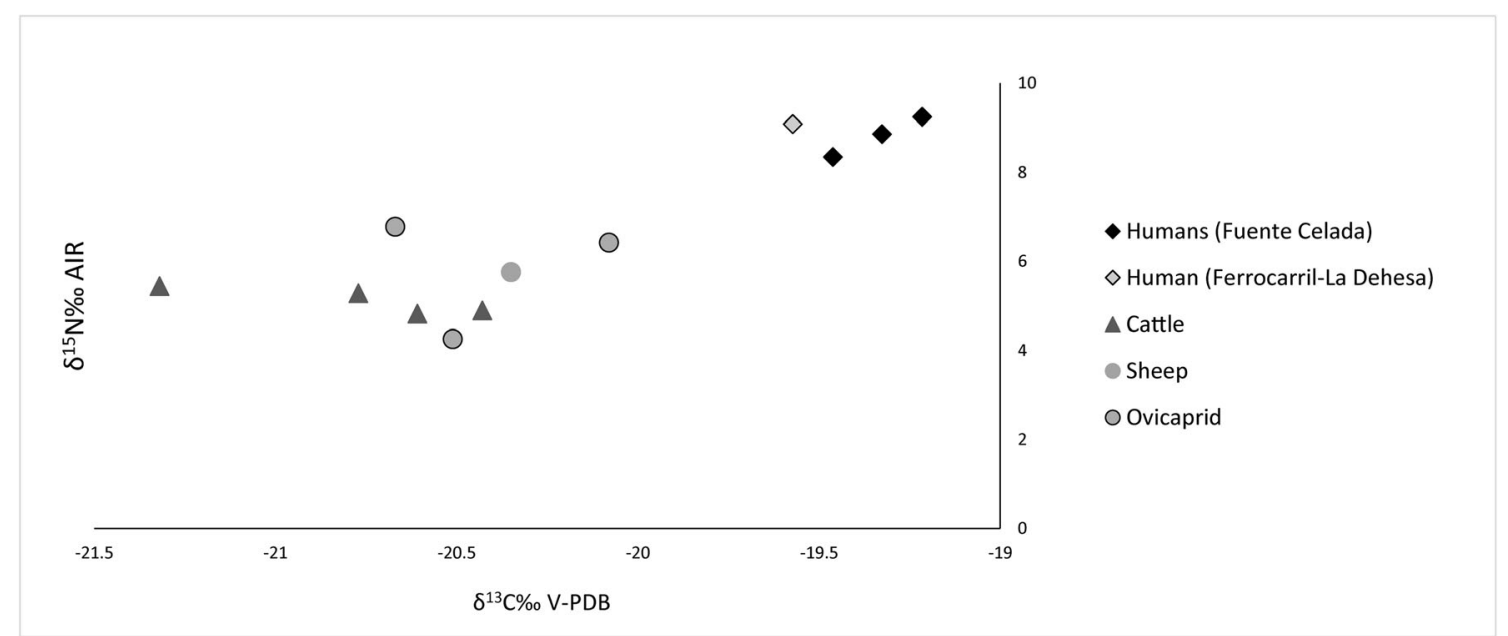

Fig. 4 Human and animal bone collagen $\delta^{15} \mathrm{~N}$ and $\delta^{13} \mathrm{C}$ values analysed from Fuente Celada plotted with the human specimen available from Ferrocarril-La Dehesa 


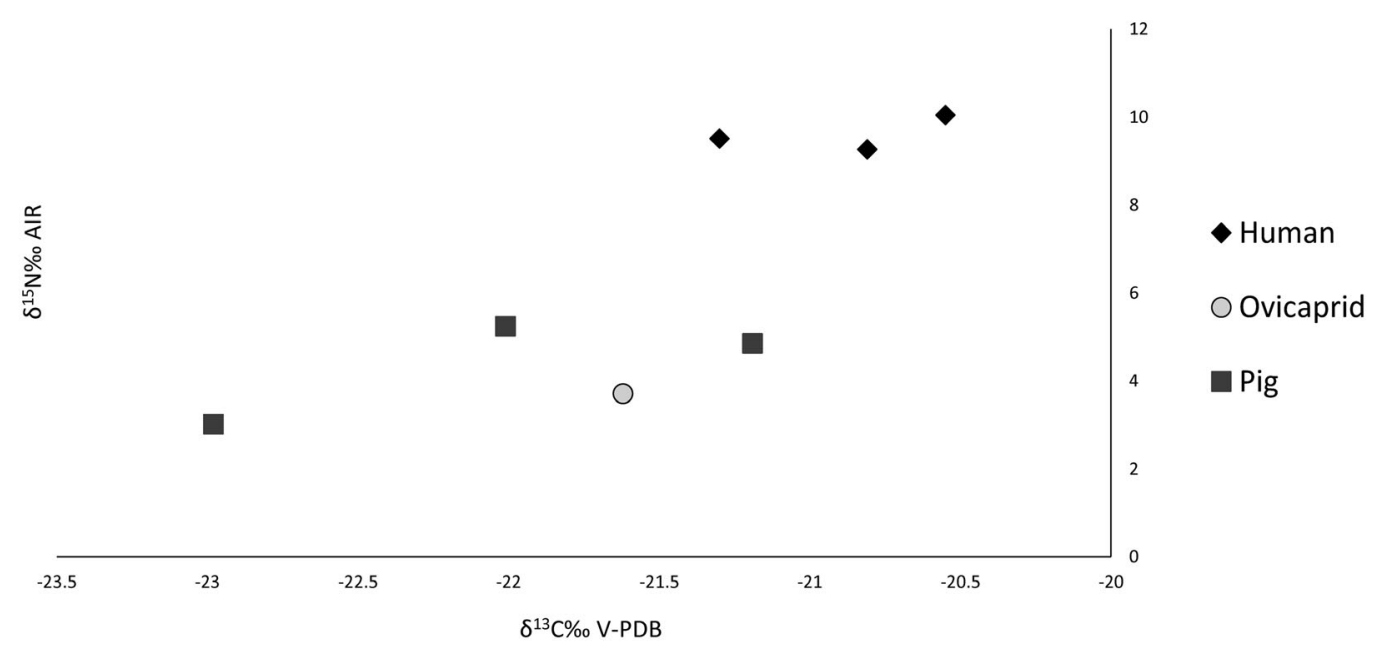

Fig. 5 Human and animal bone collagen $\delta^{15} \mathrm{~N}$ and $\delta^{13} \mathrm{C}$ values analysed from El Abrigo de la Castañera

discussed previously in the results) (Fig. 6), with humans at all sites plotting c. $3-4 \%$ higher in $\delta^{15} \mathrm{~N}$ than the contemporary herbivores. The signatures observed are consistent with a mixed diet, including animal protein, likely in the form of meat and potential milk products. The diet of Chalcolithic, Neolithic and Bronze Age individuals within these sites was relatively homogenous at least in terms of the quantity of protein consumed. This initial evidence contrasts with evidence from the Late Neolithic/Early Chalcolithic in La Rioja Alavesa region (Basque Country), where monumental graves were observed to have higher $\delta^{13} \mathrm{C}$ and $\delta^{15} \mathrm{~N}$ values than the cave burials, consistent with potentially different agricultural strategies and access to pastures, linked to differential social status (Fernández-Crespo and Schulting 2017). Further work in the Northern Cantabrian region would help to explore potential links between burial types and social status.

The question of whether milk and dairy products were being produced and consumed at these sites remains open. The small zooarchaeological assemblages available for these sites prevent detailed mortality profiles from being generated, which can give insights into milk, meat and wool economies (Payne 1973). Cattle dominated the faunal assemblages at both Fuente Celada (Riquelme Cantal 2009) and El Hornazo (Marín-Arroyo 2011), followed by ovicaprids. Some

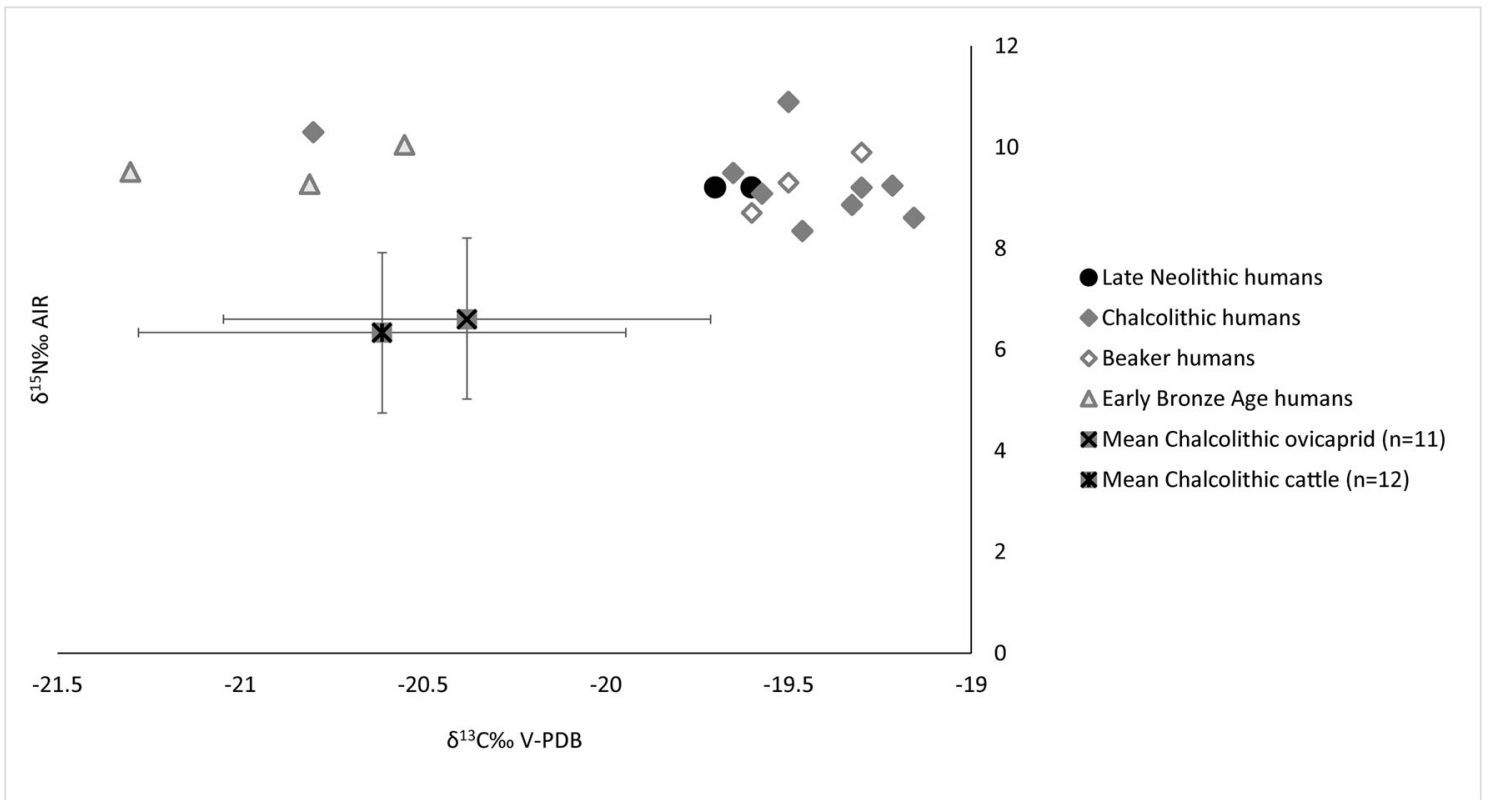

Fig. 6 Human bone collagen $\delta^{15} \mathrm{~N}$ and $\delta^{13} \mathrm{C}$ values analysed from Arroyal I, El Hornazo, Fuente Celada, Ferrocarril-La Dehesa and Abrigo de la Castañera with mean Chalcolithic ovicaprid and cattle values. Error bars represent $1 \sigma$ 
immature cattle were also identified at El Hornazo (MarínArroyo 2011), which is more typical of dairying economies (Payne 1973). The limited zooarchaeological datasets available, together with other indirect evidence, such as the analysis of the ceramic assemblages, indicate that at least from the Chalcolithic period milk was consumed, mostly from bovines (Carmona Ballestero 2013: 302-306). During the Bronze Age, vessels called encellas (cheese strainer) became commonly produced, which is considered a good indication of when dairy products like cheese became a regular part of diet (Salque et al. 2013). Lipid residue analysis of Neolithic pottery from the Iberian Peninsula showed the presence of dairy fats, with dairying thought to be taking place in open air sites (Spiteri et al. 2016), showing that the capacity for milk production existed, at least, in the Mediterranean coast and it is not unreasonable to suggest that it was part of the economy at the Northern Iberian plateau sites.

Despite the evidence of riverine fish being recorded in pottery contents in Arroyal I (Ordoñez et al. 2017) and La Castañera (Vega-Maeso, pers. comm.), there is no evidence of routine freshwater fish or marine protein consumption at these sites visible in the bone collagen evidence. This suggests that, if they were being consumed at the sites, then it was not in sufficient quantities to be registered in the long-term bone collagen record and would indicate infrequent or occasional use of these resources. Similar stable isotope studies carried out in Neolithic and Chalcolithic sites across the Iberian Peninsula show similar results with no evidence of aquatic resource consumption registering in bone collagen values achieved (Arias Cabal 2005; Fernández-Crespo and Schulting 2017; Fontanals-Coll et al. 2015; Salazar-García 2011; Sarasketa-Gartzia et al. 2018).

In terms of possible plant material available, wheat and barley are the most commonly identified cereals of the Neolithic-Bronze Age in the Iberian Peninsula (Buxó and Piqué 2008) and crucial plant sources within human diet. It is possible that pulses, such as peas, lentils and fava beans, which appear in the Iberian Peninsula from the early Neolithic onwards (Zapata et al. 2004), were also a component of diet at this time. Of the terrestrial $\mathrm{C}_{4}$ plants, millet is documented in the Iberian Peninsula during the 3-2nd Millenia BCE, before becoming more widely cultivated in the 1st millennium BCE (Buxó and Piqué 2008; Moreno-Larrazabal et al. 2015). Foxtail millet (Setaria italica) was identified in Kobaederra cave during Chalcolithic (c. 3331-2906 BCE) and Arenaza during the Bronze Age (c. 2136-1746 BCE) (Zapata 2002), both sites located in Bizkaia (Basque Country). In the studied sample, if $\mathrm{C}_{4}$ plants were a component of human diet, then they were not being consumed in sufficient quantities to register in the bone collagen record. Other studies of Neolithic, Chalcolithic and Bronze Age diets in Spain show similar results with $\mathrm{C}_{3}$ signatures evidence in Neolithic and Chalcolithic Iberia (Fernández-Crespo and Schulting 2017; Fernández-
Crespo et al. 2018; Fontanals-Coll et al. 2015; SarasketaGartzia et al. 2018).

At the sites analysed, the carpological record for Fuente Celada was sparse with only 13 fragments of plant remains recorded (from Pits 42 and 35), showing the presence of wild strawberry (Fragaria vesca), bread/macaroni wheat (Triticum aestivum/durum) and emmer (Triticum sp.). Despite being a small assemblage, it gives an insight into the crops being produced by these populations and in the case of the wild strawberry, the plants available in the wider area. Wild resources have also been identified in assemblages from the North-East of the Iberian Peninsula including, acorns, hazelnuts and wild grapes (Antolín and Jacomet 2015), indicating that wild plants may have played an important role in diet, alongside the domestic crops. In El Hornazo, a storage pit (Pit 130) with intact contents, including a mixture of wheat (Triticum aestivum/durum) and sloes (Prunus spinosa) was preserved (López-Dóriga et al. 2011). One of the limitations of stable isotope analysis is that it is biassed towards representing protein consumption, meaning that there is a trend towards representing high protein products, such as those from animals, which can mask the contribution of plants to diet (Hedges and Reynard 2007) and, knowing the exact proportions of plant contributions to diet is challenging to establish.

\section{Insights into animal management in northern Spain}

The small number of animal remains studied for stable isotope analysis means that it is only possible to make tentative comments about the animal management strategies used at the sites, but can provide initial insights into prehistoric pastoralism in Nothern Spain. The range of $\delta^{13} \mathrm{C}$ values of the herbivores was all consistent with those expected for open $\mathrm{C}_{3}$ environments.

The stable isotope values of the faunal remains from Fuente Celada showed relatively large ranges in $\delta^{13} \mathrm{C}$ values of cattle and $\delta^{15} \mathrm{~N}$ values of sheep, indicating that these animals were not necessarily consuming a homogenous diet. It is possible that a range of different pastures was used, resulting in isotopically dispersed values of those animals. The scale of movement of animals between pastures is a matter of debate. Sheep transhumance from the Neolithic period onwards has been identified using incremental analysis of tooth bioapatite $\delta^{13} \mathrm{C}$ and $\delta^{18} \mathrm{O}$ values (Tornero et al. 2018), which in the bone collagen record of animals could produce averaged values that differ from each other, especially if animal movements vary seasonally or annually. Transhumance over larger distances requires relatively complex infrastructure in terms of territories occupied in the wider landscape and would be logistically and politically complex to negotiate (Carmona Ballestero 2013). Instead, it is possible that animals were grazed in various pastures, representing different biotopes 
within the same political regions. This scenario could be indicative of smaller scale movements within individual group territories, which is consistent with models of landscape use in Later Prehistory in Central Iberia as proposed by Díaz del Río (2001, 2006). This pattern of small-scale animal movements also identified in bone collagen $\delta^{13} \mathrm{C}$ and $\delta^{15} \mathrm{~N}$ analysis at the prehistoric site of Danebury (United Kingdom), where animals kept in different parts of the landscape had characteristically different $\delta^{13} \mathrm{C}$ and $\delta^{15} \mathrm{~N}$ values (Stevens et al. 2013). Another explanation could be that different fodder was used, at different times, during the occupation of the site, and could suggest changing agrarian economies.

The faunal cattle and sheep with higher $\delta^{15} \mathrm{~N}$ values may represent younger animals exhibiting a nursing effect, which typically elevates $\delta^{15} \mathrm{~N}$ by approximately one trophic level due to the consumption of their mother's breastmilk (e.g. Schurr 1997; Fuller et al. 2006) and could explain their elevated $\delta^{13} \mathrm{C}$ and $\delta^{15} \mathrm{~N}$ values relative to other herbivores at the site. Whilst individuals did not have the porous bone structure, typically associated with infantile individuals, the lack of distal ends of bones with fusion evidence means that they could be animals exhibiting nursing signatures. The cow labelled as individual 'a' in Fig. 3 has an unusually high $\delta^{15} \mathrm{~N}$ value of $8.8 \%$, combined with a lower $\delta^{13} \mathrm{C}$ value of $-21.5 \%$. The lower $\delta^{13} \mathrm{C}$ suggests that this individual may have been raised on an isotopically different region to the other individuals analysed. This may be indicative of the use of multiple pasture landscapes in the management of animals, with pastures further afield potentially being used to raise animals before bringing them to the site for slaughter. This could be due to seasonal uses of different tracts of land, which if used routinely could impact on the long-term bone collagen record of an individual. Another possibility is that this animal bone could be from an animal trade on the hoof or a cut of meat traded to the site. The trade of perishable goods is relatively complex to track archaeologically, in comparison to items such as ceramics or lithics. Zooarchaeological methods can often distinguish between producer and consumer sites, where trade and exchange were central to the economy (Crabtree 1990), but occasional or infrequent trade or exchange of animals would require individual life histories of animals to be created and is more complex to establish when only small assemblages are available. Future incremental analysis of available animal teeth for $\delta^{13} \mathrm{C}$ and $\delta^{18} \mathrm{O}$ analysis would help to establish more about Prehistoric landscape use and could provide insights into the possible exchange of animals.

The similarity in the wild red deer $\delta^{15} \mathrm{~N}$ value from El Hornazo and the majority of the domestic herbivores at the site (and at Fuente Celada, also located in the same village) suggest that sheep and cattle were occupying similar parts of the landscape as the red deer. A further implication, based on the similarity of $\delta^{15} \mathrm{~N}$ values of the wild and domestic species, is that the cattle and sheep analysed were not fed on crops that were enriched with manure, which would then produce elevated $\delta^{15} \mathrm{~N}$ values in plants (Bogaard et al. 2007) and thus consumers of these plants. The $\delta^{13} \mathrm{C}$ values of the domestic herbivores are slightly lower than the wild red deer (which would not typically be subjected to anthropogenic management processes) and could hint at the cattle and sheep being fed on some domestic crops, potentially as winter fodder. Differences in the stable isotope values of wild and domestic species at the Neolithic site of La Draga was also attributed to the use of crops as fodder for the domestic stock (Navarrete et al. 2017), which supports this hypothesis.

The three suid specimens sampled at El Abrigo de la Castañera had different diets. One of the Sus sampled had a lower $\delta^{13} \mathrm{C}$ value, which is characteristic of an animal feeding in a forested environment (van der Merwe and Medina 1991). Osteologically, it was not possible to determine if these animals were domestic or wild. If these individuals were all domestic, the implication is that differential animal management was being employed. Studies of Neolithic pigs in England have shown that domestic pigs may have been herded under partially wooded environments (Hamilton et al. 2009). This may, to some extent, have been a method of protecting crops from pig rooting, which can damage plants and shoots (Ballari and Barrios-García 2014). Alternatively, the specimen from La Castañera may be a wild boar, which typically inhabit forested environments and would explain the lower $\delta^{13} \mathrm{C}$ value. If true, this would suggest that wild animals were exploited, either through targeted hunting or chance encounter. The presence of red deer in the faunal assemblages at Fuente Celada (Riquelme Cantal 2009) and El Hornazo (Marín-Arroyo 2011) also shows that wild animals were used, as an occasional supplementary resource for these farming populations, and wild boar may also have been an additional resource exploited.

\section{The relationship between humans and dogs}

Dogs have been used as a proxy for human dietary behaviour (e.g. Clutton-Brock and Noe-Nygaard 1990; Fischer et al. 2007; Schulting and Richards 2002b) and how far they accurately represent human diet in archaeological populations has been debated (Guiry 2012). It is generally accepted that the diet of dogs generally tracks that of the human population they live with, irrespective of temporal and geographical situation or the culture of populations (Guiry and Grimes 2013). The Chalcolithic dog from Arroyal I was indistinguishable from the human $\delta^{13} \mathrm{C}$ and $\delta^{15} \mathrm{~N}$ values, indicating that this animal had a similar diet to the humans, either through intentionally being fed scraps from the human table or scavenging refuse from human waste. At El Hornazo, the situation is more complex also during Chalcolithic, with one dog reflecting the human diet exactly plotting alongside the humans, and three other dogs plotted with the herbivores. This suggests that dogs 
are not necessarily a good proxy for human diet in this region. The difference in the diet of the dogs may represent the role of dogs at the site, in terms of whether they are household pets, being fed scraps from the human table (including meat) or whether they were working animals, that may have consumed a more regimented diet comprising predominantly of vegetal matter.

\section{Prehistoric population movements in the northern Iberian Peninsula}

The movement of human populations during Neolithic, Chalcolithic and Bronze Age period in Europe is currently a subject of great interest and genetic evidence has demonstrated links between Neolithic Iberian populations and central European Beaker populations (Olalde et al. 2018), indicating the large-scale movements involved. The large difference between the $\delta^{34} \mathrm{~S}$ values of the two individuals analysed from Arroyal I suggests that they were not from the same location, which is also supported by SUC28 having a lower $\delta^{13} \mathrm{C}$ value than other individuals in the population analysed. Published relationships of $\delta^{34} \mathrm{~S}$ values show that within living populations, an average range of $1.9 \%$ in sulphur values is observed, with slightly higher range of $2.4 \%$ o between archaeological populations (Nehlich 2015: 8). The large difference between the $\delta^{34} \mathrm{~S}$ values of both individuals indicates that these people lived in different locations before they came to be interred at the site. It could be suggested that individual SUC28 came from a more saline or coastal environment due to the higher $\delta^{34} \mathrm{~S}$ value. The effect of salinity on $\delta^{34} \mathrm{~S}$ values has been demonstrated, with coastal $\delta^{34} \mathrm{~S}$ values reaching up to +20 (Nehlich 2015). The effects of salinity on baseline $\delta^{34} \mathrm{~S}$ values can reach distances of up to $30 \mathrm{~km}$ from the coast, although the effects become less potent with distance (c. 10\%o) (Nehlich 2015). The $\delta^{13} \mathrm{C}$ of individuals can also be affected by salinity, although archaeological studies of human and animal bone show that sea spray can cause elevated $\delta^{34} \mathrm{~S}$ of $\sim+14$ to + 18 whilst still producing $\delta^{13} \mathrm{C}$ values of $\sim-23$ to $-21 \%$ o (Nehlich 2015, based on data from Craig et al. 2006; Fornander et al. 2008; and Linderholm et al. 2008a, b). A likely location of origin of this person could be, perhaps further north, towards the Cantabrian coast, which is geographically the closest coastline to the site. This hypothesis is supported by the individual having a $\delta^{13} \mathrm{C}$ that plots within the range of humans analysed at El Abrigo de la Castañera, which is also located in Cantabria (Fig. 1). Recent work at the sites of Santimamiñe and Pico Ramos, in the Basque Country, exploring late Neolithic and Chalcolithic populations using ${ }^{87} \mathrm{Sr} /{ }^{86} \mathrm{Sr}$ analysis demonstrated that there were movements of the populations between the Pyrenees to the Biscayan coast (Sarasketa-Gartzia et al.2018), showing that there was fluidity in the population of earlier prehistoric populations in the Northern Iberian Peninsula. In Arroyal I, there is no other evidence of contact with the coast, despite its relative proximity. In contrast, El Hornazo contained one of the few maritime shells located in a non-funerary Chalcolithic inner context (Gutiérrez Zugasti et al. 2014). Until now, seashells were the only signs of contact between the inland inhabitants of the North Castilian plateau and the coast. Therefore, smaller scale intra-regional movements might have been common also during the period and region of study in these farming populations.

Studies of ceramics from the Cantabrian Region provides further evidence for the movement of populations in Prehistory (Vega Maeso 2017). The distribution of decorative motifs and shapes on pottery artefacts appear to relate to the movement of people, particularly women, rather than the exchange of vessels (Vega Maeso 2017). The tentative results from this, also indicate that the individuals buried at Arroyal I are not necessarily all local to the area and supports other evidence for population movement within the Iberian Peninsula during the Chalcolithic and Bronze Age periods. A similar hypothesis was proposed at the Chalcolithic site of La Atalayuela in La Rioja, where two individuals interred at the site with outlying $\delta^{13} \mathrm{C}$ values were interpreted as potentially being from different regions (Fernández-Crespo et al. 2018) again suggesting population fluidity within different regions in Prehistoric Northern Spain.

\section{Conclusions}

This study has provided valuable insights into the economy, animal management and mobility of early farmers of the Northern Spain Plateau, a region which has received little attention so far. Analysis of bone collagen $\delta^{13} \mathrm{C}$ and $\delta^{15} \mathrm{~N}$ values from human remains from different mortuary sites dating between the Neolithic and Bronze Age shows that the diet of individuals analysed was remarkably similar. Humans consumed a predominantly $\mathrm{C}_{3}$ terrestrial diet, including animal protein (meat and likely milk/dairy products) and wider regional archaeobotanical evidence suggests that diet would also have included $\mathrm{C}_{3}$ plants, such as wheat and barley and vegetables. The faunal samples provided insights into animal management. The diversity in $\delta^{13} \mathrm{C}$ and $\delta^{15} \mathrm{~N}$ values suggests a wider use of the landscape in the management of herbivores, possibly with the access of animals to different pastures with diverse biotopes. Further work using tooth incremental isotope analysis would be valuable in exploring this concept and to explore whether there is evidence of seasonal changes in diet related to animal movements or foddering strategies. Differences were observed between individuals from the coast and those of the interior, with lower $\delta^{13} \mathrm{C}$ values likely due to baseline environmental differences between the two regions and $\delta^{34} \mathrm{~S}$ analysis of two individuals suggests a level of inland mobility during this time. Based on the similarities of diets 
between individuals analysed, it appears that the socioeconomic conditions experienced between the Neolithic and Bronze age in central Northern Spain remained stable or without remarkable dietary changes. This study has helped to expand our understanding of diet, economy and lifeways of an understudied location, where few skeletal remains are available and has demonstrated the need for further research in the region to provide detailed reconstructions of agricultural practises, diet and mobility of Prehistoric populations.

Acknowledgements The authors would like to thank Ignacio Valera (IBBTEC, University of Cantabria) for his help and support in setting up the collagen extraction protocol and for allowing us to use his laboratory facilities. Thank you also to Carlos Revilla Gómez (IBBTEC, University of Cantabria) for his laboratory assistance. Lucía Agudo Pérez (IIIPC, University of Cantabria) provided invaluable technical support during sampling and sample preparation. The authors would like to thank Marta Negro Cobo, director of the Museum of Burgos for allowing us to sample the remains from El Hornazo and Fuente Celada and for facilitating access to the collections.

Funding information This research was funded by the Santander Bank Programme Talent Attraction for Research - STAR1 at the University of Cantabria (2017-2020) to ABMA.

\section{References}

Alameda Cuenca-Romero MC, Carmona Ballestero E, Pascual Blanco S, Martínez Díez G, Díez Pastor C (2011) El "campo de hoyos" calcolítico de Fuente Celada (Burgos): datos preliminares y perspectivas. Complutum 22(1):47-69

Altuna J (1980) Historia de la domesticación animal en el País Vasco desde sus orígenes hasta la romanización. Munibe AntropologiaArqueologia 32:129-163

Altuna J, Mariezkurrena K (2012) Macromammalian remains from the Holocene levels of El Mirón cave. In El Mirón Cave, Cantabrian Spain. The site and Its Holocene archaeological record pp. 288-319

Altuna J, Mariezkurrena K (2011) Restos de alimentación de origen animal de los pobladores de la cueva de Arenaza I País Vasco durante la Edad del Bronce. Veleia 24-25:843-877

Ambrose SH (1993) Isotopic analysis of paleodiets: methodological and interpretive considerations. In: Sandford MK (ed) Investigations of ancient human tissue: chemical analysis in anthropology. Gordon and Breach, Langthorne, pp 59-130

Antolín F, Jacomet S (2015) Wild fruit use among early farmers in the Neolithic (5400-2300 cal bc) in the north-east of the Iberian Peninsula: an intensive practice? Veg Hist Archaeobotany 24(1): 19-33

Arias Cabal P (2005) Determinaciones de isótopos estables en restos humanos de la región Cantábrica: aportación al estudio de la dieta de las poblaciones del Mesolítico y el Neolítico. Munibe Antropologia-Arkeologia 57:359-374

Ballari SA, Barrios-García MN (2014) A review of wild boar Sus scrofa diet and factors affecting food selection in native and introduced ranges. Mammal Rev 44(2):124-134

Bernabeu J (2003) Del Neolítico a la Edad del Bronce. In Vega Toscano G. Bernabeu Aubán J. \& Chapa Brunet T.; La Prehistoria, Síntesis, Madrid: 113-174

Bogaard A, Heaton TH, Poulton P, Merbach I (2007) The impact of manuring on nitrogen isotope ratios in cereals: archaeological implications for reconstruction of diet and crop management practices. J Archaeol Sci 34(3):335-343

Buxó R, Piqué R (2008) Arqueobotánica: los usos de las plantas en la Península Ibérica. Barcelona, Ariel

Carmona Ballestero E (2013) El Calcolítico en la cuenca media del Arlanzón (Burgos, España): Comunidades campesinas, procesos históricos y transformaciones. Archaeopress, Oxford

Carmona Ballestero E, Arnaiz Alonso MA (in press) Stratigraphic events and 'cycles of use' in the dolmen of Arroyal I. In: Rojo Guerra MA, Tejedor-Rodríguez C (eds) Biografias Megalíticas Proceedings of XVII World UISPP Congress

Carmona Ballestero E, Pascual Blanco S, Vega J (2013) Restos humanos, contextos funerarios y diversidad formal: los yacimientos calcolíticos de El Hornazo y El Túmulo IL. C1 de Cótar (Burgos). Revista Atánntica-Mediterránea de Prehistoria y Arqueologìa Social 15(1):53-80

Castaños P (1984) Estudio de los macromamíferos de la cueva de Santimamiñe. Kobie 14:235-218

Chisholm BS, Nelson DE, Schwarcz HP (1982) Stable carbon isotope ratios as a measure of marine versus terrestrial protein in ancient diets. Science 216:1131-1132

Clutton-Brock J, Noe-Nygaard N (1990) New osteological and C-isotope evidence on Mesolithic dogs: companions to hunters and fishers at Star Carr, Seamer Carr and Kongemose. J Archaeol Sci 17:643-653

Crabtree PJ (1990) Zooarchaeology and complex societies: some uses of faunal analysis for the study of trade, social status, and ethnicity. Archaeol Method Theory 2:155-205

Craig OE, Ross R, Andersen SH, Milner N, Bailey GN (2006) Focus: sulphur isotope variation in archaeological marine fauna from northern Europe. J Archaeol Sci 33(11):1642-1646

Delibes de Castro G, Fernández Manzano J (2000) La trayectoria cultural de la Prehistoria Reciente (6400-2500 BP) en la Submeseta Norte española: principales hitos de un proceso, En III Congreso de Arqueología Peninsular, ADECAP, vol: IV Porto. pp: 95-122

Delibes de Castro G, Fernández-Miranda M (1993) Los orígenes de la civilización. El Calcolítico en el Viejo Mundo. Síntesis, Madrid

Delibes de Castro G, Herrán Martínez JI; Santiago Pardo Jy Val Recio J del (1995) Evidence for social complexity in the Copper Age of the Northern Meseta. In Lillios, K.T. (ed.). The Origins of Complex Societies in Late Prehistoric Iberia, Michigan: University of Michigan International Monographs in Prehistory 8. Ann Arbor: 44-63

DeNiro MJ (1985) Post-mortem preservation and alteration of in vivo bone collagen isotope ratios in relation to paleodietary reconstruction. Nature 317:806-809

Díaz del Río P (2001) La formación del paisaje agrario: Madrid en el III y II milenios BC. In: Arqueología, Paleontología y Etnografía. Artes de la Comunidad de Madrid, Consejería de las

Díaz del Río P (2006) An appraisal of social inequalities in Central Iberia (c. 5300-1600 CAL BC). In Díaz del Río, P. García San Juan, L. (eds): Social inequality in Iberian late prehistory. BAR International Series 1525, Oxford: BAR. Pp 67-79

Fernández-Crespo T, Schulting RJ (2017) Living different lives: early social differentiation identified through linking mortuary and isotopic variability in Late Neolithic/Early Chalcolithic north-central Spain. PLoS One 12(9):0177881

Fernández-Crespo T, Ordoño J, Barandiarán I, Andrés MT, Schulting RJ (2018) The bell beaker multiple burial pit of La Atalayuela (La Rioja, Spain): stable isotope insights into diet, identity and mortuary practices in Chalcolithic Iberia. Archaeol Anthropol Sci. https://doi. org $/ 10.1007 / \mathrm{s} 12520-018-0610-1$

Fischer A, Jesper Olsen B, Richards M, Heinemeier J, Sveinbjörnsdóttire AE, Bennike P (2007) Coast-inland mobility and diet in the Danish Mesolithic and Neolithic: evidence from stable isotope values of humans and dogs. J Archaeol Sci 34:2125-2150 
Fontanals-Coll M, Subirà ME, Bonilla MDZ, Duboscq S, Gibaja JF (2015) Investigating palaeodietary and social differences between two differentiated sectors of a Neolithic community, La Bòbila Madurell-Can Gambús (north-east Iberian Peninsula). J Archaeol Sci Rep 3:160-170

Fornander E, Eriksson G, Lidén K (2008) Wild at heart: approaching pitted ware identity, economy and cosmology through stable isotopes in skeletal material from the Neolithic site Korsnäs in Eastern Central Sweden. J Anthropol Archaeol 27(3):281-297

Fuller BT, Fuller JL, Harris DA, Hedges RE (2006) Detection of breastfeeding and weaning in modern human infants with carbon and nitrogen stable isotope ratios. Am J Phys Anthropol 129(2): 279-293

Garcia Sanjuán L and Murillo-Barroso M (2013) Social complexity in copper age southern Iberia (ca. 3200-2200 cal b.c.): reviewing the state hypothesis at Valencina de la Concepción (Seville, Spain) . Prehistory Iberia. Debating Early Soc. Strat. State. Pp. 119-140

Garrido-Pena R (2014) Bell Beakers in Iberia. In M. Almagro (ed) (2014): Iberia. Protohistory of the far west of Europe: from Neolithic to Roman conquest Universidad de Burgos Fundación Atapuerca: 113-124

Gomarín Guirado F (1972) Dos nuevo yacimientos de la Edad del Bronce en Santander. Zephyrus, XXIII-XXIV, 193-195

Guiry EJ (2012) Dogs as analogues in stable isotope-based human paleodietary reconstructions: a review and considerations for future use. J Archaeol Method Theory 19:351-376

Guiry EJ, Grimes V (2013) Domestic dog (Canis familiaris) diets among coastal late archaic groups of northeastern North America: a case study for the canine surrogacy approach. J Anthropol Archaeol 32(4):732-745

Gutiérrez Zugasti I, Carmona Ballestero E, Cuenca Solana D, Pascual Blanco S and Vega y Miguel JJ (2014) El papel de los moluscos de agua dulce durante el Calcolítico en la Meseta. una visión desde el yacimiento de El Hornazo (Villimar, Burgos). In Juan Jesús Cantillo Duarte, Darío Bernal Casasola, José Ramos Muñoz (eds.). Molusco y púrpura en contextos arqueológicos atlánticomediterráneos: nuevos datos y reflexiones en clave de proceso histórico, Universidad de Cadiz: 107-116

Hamilton J, Hedges RE, Robinson M (2009) Rooting for pigfruit: pig feeding in Neolithic and iron age Britain compared. Antiquity 83(322):998-1011

Hedges RE, Reynard LM (2007) Nitrogen isotopes and the trophic level of humans in archaeology. J Archaeol Sci 34(8):1240-1251

Jones JR, Mulville J (2016) Isotopic and zooarchaeological approaches towards understanding aquatic resource use in human economies and animal management in the prehistoric Scottish North Atlantic Islands. J Archaeol Sci Rep 6:665-677

Jones JR, Mulville JA (2018) Norse animal husbandry in liminal environments: stable isotope evidence from the Scottish North Atlantic Islands. Environ Archaeol 23:338-351. https://doi.org/10.1080/ 14614103.2018.1439678

Linderholm, A., Grundberg, L., Mörth, C.M., Andersson, K., Lidén, K. and Hårding, B., 2008a. An early Christian cemetery at Björned in northern Sweden: stable isotope a-nalyses of skeletal material. Fornvännen: Journal of Swedish Antiquarian Research 103(3): 176-189

Linderholm A, Jonson CH, Svensk O, Lidén K (2008b) Diet and status in Birka: stable isotopes and grave goods compared. Antiquity 82(316):446-461

López-Dóriga IL, Ballestero EC, Blanco SP, Miguel JVY (2011) Análisis de restos carpológicos de los yacimientos arqueológicos de Fuente Celada y el Hornazo (Burgos). Munibe Antropologia-Arkeologia 62:289-302

Mariezkurrena K (1990) Caza y domesticación durante el Neolítico y Edad de los Metales en el País Vasco. Munibe 42:241-252
Marín-Arroyo AB (2011) Los recursos faunísticos de Fuente Celada. Unpublished report

Moreno-Larrazabal A, Teira-Brión A, Sopelana-Salcedo I, ArranzOtaegui A, Zapata L (2015) Ethnobotany of millet cultivation in the north of the Iberian Peninsula. Veget Hist Archaeobot 24(4): 541-554

Müldner G, Britton K, Ervynck A (2014) Inferring animal husbandry strategies in coastal zones through stable isotope analysis: new evidence from the Flemish coastal plain (Belgium, 1st-15th century AD). Journal of Archaeological Science 41:322-332

Navarrete V, Colonese AC, Tornero C, Antolín F, Von Tersch M, Eulàlia Subirà M, Comes P, Rosell-Melé A, Saña M (2017) Feeding management strategies among the early Neolithic pigs in the NE of the Iberian Peninsula. Int J Osteoarchaeol 27(5):839-852

Nehlich O (2015) The application of sulphur isotope analyses in archaeological research: a review. Earth Sci Rev 142:1-17

Nehlich O, Richards MP (2009) Establishing collagen quality criteria for sulphur isotope analysis of archaeological bone collagen. Archaeol Anthropol Sci 1(1):59-75

Oelze VM, Siebert A, Nicklisch N, Meller H, Dresely V, Alt KW (2011) Early Neolithic diet and animal husbandry: stable isotope evidence from three Linearbandkeramik (LBK) sites in Central Germany. J Archaeol Sci 38(2):270-279

Olalde I, Brace S, Allentoft ME, Armit I, Kristiansen K, Booth T, Rohland N, Mallick S, Szécsényi-Nagy A, Mittnik A, Altena E (2018) The beaker phenomenon and the genomic transformation of Northwest Europe. Nature 555(7695):190-196

Ontañón Peredo R (2003) Caminos hacia la complejidad. El Calcolítico en la región cantábrica. Servicio de Publicaciones de la Universidad de Cantabria, Santander

Ordoñez Santaolalla O; Vega Maeso, C.; Jaime Moreno, I, Palmero Díaz, S. and Carmona Ballestero, E. (2017): Absorption and degradation of fatty acids in prehistoric ceramics: a preliminary study. In Rodrigo Alonso, Javier Baena \& David Canales (eds); Playing with the time. Experimental archaeology and the study of the past, Servicio de Publicaciones de la Universidad Autónoma de Madrid. pp. 177-182

Payne S (1973) Kill-off patterns in sheep and goats: the mandibles for Asvan Kale. Anatol Stud 23:281-303

Peel MC, Finlayson BL, McMahon TA (2007) Updated world map of the Koppen-Geiger climate classification. Hydrol Earth Syst Sci 11: 1633-1644

Peréz Ripoll M, López Gila MD (2012) Taphonomic study of the large and medium mammal from the post-Paleolithic occupations in El Mirón cave. In: Strauss LG, González Morales MR (eds) El Mirón Cave, Cantabrian Spain: The Site and Its Holocene Archaeological Record pp. 262-287. University of New Mexico Press

Pollard AM (2007) Analytical chemistry in archaeology. Cambridge University Press

Richards MP, Hedges REM (1999) Stable isotope evidence for similarities in the types of marine foods used by late Mesolithic humans at sites along the Atlantic coast of Europe. J Archaeol Sci 26:717-722

Rincón Vila R (1982) Contribución al conocimiento de la estratigrafía prehistórica en las cuevas de Castro Urdiales. Cuadernos de Espeleologia 9-10:27-74

Rincón Vila R (1985) Las culturas del metal. In: García Guinea MA (ed) Historia de Cantabria: prehistoria, edades antigua y media. Estudio, Santander, pp 113-210

Riquelme Cantal JA (2009) Estudio faunístico de los restos óseos procedentes del yacimiento calcolítico precampaniforme de Villimar (Burgos). Campaña de 2006. Unpublished report

Rojo Guerra M, Garrido-Pena R and García-Martínez de Lagrán I (2005) El Campaniforme en la Península Ibérica y su contexto europeo. Bellbeakers in the Iberian Peninsula and their European context. (Universidad de Valladolid, Secretariado de Publicaciones e Intercambio Editorial) 
Rojo Guerra M, García-Martínez de Lagrán I, Garrido-Pena R (2012) El neolítico en la península ibérica y su contexto europeo. Cátedra, Madrid

Ruiz Cobo J (1991) Implantación y desarrollo de las economías de producción en Cantabria. Tesis doctoral inédita. Departamento de Ciencias Históricas. Universidad de Cantabria, Santander

Ruiz Cobo J (1996) El Abrigo de la Castañera Obregón, Villanueva de Vullaescusa : materiales arqueológicos. Boletín Cántabro de Espelología 12:123-128

Ruiz Cobo J, Serna González MR (1999) Cerámicas incisas en cuevas de Cantabria. Veleia 7:61-78

Salazar-García DC (2011) Aproximación a la dieta de la población calcolítica de La Vital a través del analisis de isotopos estables del carbono y del nitrógeno sobre restos óseos. In: Perez G, Bernabeu J, Carrion y, Garcia O, Molina L, Gomez M, editors. La Vital (Gandia, Valencia) Vida y muerte en la desembocadura del Serpis durante el III y el I milenio a.C. Servicio de Investigacion Prehistórica del Museo de Prehistoria de Valencia. Series de Trabajos Varios 113. Valencia: Diputación de Valencia, Museu de Prehistòria de València; 2011. pp. 139-143

Salazar-García DC, Aura JE, Olària CR, Talamo S, Morales JV, Richards MP (2014) Isotope evidence for the use of marine resources in the eastern Iberian Mesolithic. J Archaeol Sci 42:231-240

Salque M, Bogucki PI, Pyzel J, Sobkowiak-Tabaka I, Grygiel R, Szmyt M, Evershed RP (2013) Earliest evidence for cheese making in the sixth millennium BC in northern Europe. Nature 493(7433):522

Sarasketa-Gartzia Izaskun, Vanessa Villalba-Mouco, Petrus le Roux, Álvaro Arrizabalaga, and Domingo C. Salazar-García (2018) Late Neolithic-Chalcolithic socio-economical dynamics in northern Iberia. A multi-isotope study on diet and provenance from Santimamiñe and Pico Ramos archaeological sites (Basque Country, Spain). Quaternary International . https://doi.org/10.1016/ j.quaint.2017.05.049

Schoeninger MJ, De Niro MJ (1984) Nitrogen and carbon isotopic composition of bone collagen from marine and terrestrial animals. Geochim Cosmochim Acta 48:625-639

Schoeninger MJ, De Niro MJ, Tauber H (1983) Stable nitrogen isotope ratios of bone collagen reflect marine and terrestrial components of prehistoric human diet. Science 220:1381-1383

Schulting RJ, Richards MP (2002) The wet, the wild and the domesticated: the Mesolithic Neolithic transition on the west coast of Scotland. Eur J Archaeol 5:147-189

Schulting RJ, Richards MP (2002b) Dogs, ducks, deer and diet: new stable isotope evidence on early Mesolithic dogs from the Vale of Pickering, Northeast England. J Archaeol Sci 29:327-333

Schulting R, Sheridan A, Crozier R and Murphy E (2010) Revisiting Quanterness: new AMS dates and stable isotope data from an Orcadian chamber tomb. In Proceedings of the Society of Antiquaries of Scotland (Vol. 140, No. 1). Edinburgh: Society of Antiquaries of Scotland

Schurr MR (1997) Stable nitrogen isotopes as evidence for the age of weaning at the angel site: a comparison of isotopic and demographic measures of weaning age. J Archaeol Sci 24(10):919-927

Sierra Sainz-Aja, A. 2014 . Subsistencia y modos de vida durante la Prehistoria Reciente en Cantabria Los restos arqueofaunísticos y antropológicos del Abrigo de la Castañera. Master Disertattion. Universidad de Cantabria

Spiteri CD, Gillis RE, Roffet-Salque M, Navarro LC, Guilaine J, Manen C, Muntoni IM, Segui MS, Urem-Kotsou D, Whelton HL, Craig OE (2016) Regional asynchronicity in dairy production and processing in early farming communities of the northern Mediterranean. Proc Natl Acad Sci 113(48):13594-13599

Stevens RE, Lightfoot E, Hamilton J, Cunliffe BW, Hedges RE (2013) One for the master and one for the dame: stable isotope investigations of Iron age animal husbandry in the Danebury environs. Archaeol Anthropol Sci 5(2):95-109

Stevens, R. E., Hermoso-Buxán, X. L., Marín-Arroyo, A. B., GonzálezMorales, M. R., and Straus, L. G. 2014. Investigation of Late Pleistocene and Early Holocene palaeoenvironmental change at El Mirón cave (Cantabria, Spain): insights from carbon and nitrogen isotope analyses of red deer. Palaeogeog. Palaeoclim, Palaeoecol. 414: 46-60

Tafuri MA, Craig OE, Canci A (2009) Stable isotope evidence for the consumption of millet and other plants in Bronze Age Italy. Am J Phys Anthropol 139(2):146-153

Tieszen LL (1991) Natural variations in the carbon isotope values of plants: implications for archaeology, ecology, and paleoecology. J Archaeol Sci 18(3):227-248

Tornero C, Aguilera M, Ferrio JP, Arcusa H, Moreno-García M, GarciaReig S, Rojo-Guerra M (2018) Vertical sheep mobility along the altitudinal gradient through stable isotope analyses in tooth molar bioapatite, meteoric water and pastures: a reference from the Ebro valley to the Central Pyrenees. Quat Int 484(10):94-106

van der Merwe NJ, Medina E (1991) The canopy effect, carbon isotope ratios and foodwebs in Amazonia. J Archaeol Sci 18(3):249-259

van Klinken GJ (1999) Bone collagen quality indicators for palaeodietary and radiocarbon measurements. J Archaeol Sci 26:687-695

Vega Maeso C (2017) La cerámica inciso-impresa en el tránsito del III al II milenio cal. B.C. en la región Cantábrica Nadir Edic . Santander. https://doi.org/10.1128/AAC.03728-14

Vicent GJ (1990) El Neolitic: tranformacions socials i economiques. In: Anfruns J, Llobet E (eds) El canvi cultural a la Prehistòria. Barcelona, Columna, pp 241-293

Vicent García J (1998) La prehistoria del modo tributario de producción, Hispania, LVIII/3 pp: 823-839

Zapata L (2002) Origen de la agricultura en el Pa1's Vasco y transformaciones en el paisaje: ana'lisis de restos vegetales arqueolo'gicos. (Kobie/Anejo 4) Bizkaiko Foru Aldundia, Bilbao

Zapata L, Peña-Chocarro L, Pérez-Jordá G, Stika HP (2004) Early Neolithic agriculture in the Iberian Peninsula. J World Prehist 18(4):283-325

Publisher's note Springer Nature remains neutral with regard to jurisdictional claims in published maps and institutional affiliations. 